\title{
Depositional setting and vertebrate biostratigraphy of the Triassic Dockum Group of Texas
}

\author{
Thomas Lehman and Sankar Chatterjee \\ Department of Geosciences, Texas Tech University, Lubbock, Texas 79409-1053, USA.
}

Triassic strata of the Dockum Group in Texas comprise two major upward-fining alluvial-lacustrine depositional sequences. The two sequences are represented by the (1) Santa Rosa-Tecovas, and (2) Trujillo-Cooper Canyon Formations. The second sequence is much thicker than the first, and occupies a greater geographic part of the Dockum basin. Each sequence of alluvial and lacustrine sediment accumulation is characterized by sediment derivation from a different source terrain. The unconformable relationship between the two depositional sequences, the change in mineralogical composition and presumed source areas between these units, differences in paleocurrent orientation between units, and evidence for intervening episodes of local deformation indicate that the sequences are of tectonic origin. These strata are not the product of a single sediment dispersal system, such as the centripetally-drained lacustrine delta complex previously envisioned for the Dockum basin. Both Dockum sequences are comprised largely of two typical alluvial facies associations; stream channel facies, and overbank flood-plain facies, that are similar to those described in nearly all fluvial deposits. In addition, the Dockum Group contains a peculiar lacustrine facies that accumulated in local flood-plain depressions, and probably resulted from subsidence over areas of subsurface salt dissolution. Vertebrate fossil assemblages are found in all three Dockum facies associations. Five fossiliferous sites in the Dockum are discussed in the context of these three depositional settings. The Dockum tetrapod diversity is reviewed in a hierarchical phylogeny with remarks on the history of collection, stratigraphic distribution of genera, and their taxonomic status. The stratigraphic ranges of tetrapod taxa do not support the recently proposed successive Otischalkian, Adamanian, Revueltian, and Apachean biochrons within the Dockum Group. Instead, a few index fossils provide a broad framework for correlation of Late Triassic nonmarine strata of the Dockum with the Carnian and Norian Alpine marine stages.

\section{Introduction}

Triassic redbeds exposed around the Southern High Plains of western Texas and eastern New Mexico constitute the fill of a major continental depocenter, the Dockum basin. These Triassic deposits have been studied by stratigraphers, sedimentologists, and paleontologists for more than a century, and are now known in some detail. Strata of the Dockum basin were deposited during the early break up of this part of the Pangean supercontinent during Late Triassic time. These strata are important in containing a record of terrestrial vertebrate life during the initial adaptive radiation of a diverse group of tetrapods including lissamphibians, turtles, lepidosaurs, trilophosaurs, phytosaurs, aetosaurs, rauisuchids, crocodylomorphs, dinosaurs, pterosaurs, birds, and mammals. Several archaic groups such as temnospondyls, prolacertiforms, dicynodonts and cynodonts, holdovers from Permian and Early Triassic faunas, are also found in the Dockum Group.

The significance of the Late Triassic time interval in the evolution of vertebrates has become increasingly appreciated over the past decade. New localities for Dockum vertebrates have been discovered

Keywords. Dockum; Triassic; Texas; sedimentology; vertebrate biostratigraphy. 
and explored, and these provide valuable data about Late Triassic terrestrial communities. In contrast to collections amassed earlier in the century, small tetrapods ('microvertebrates', with body length $\sim 50 \mathrm{~cm}$ ) are found to dominate the fauna in some places. The Dockum fauna is typical of Late Triassic continental assemblages not only in North America, but also in most of the Pangean supercontinent. Apparently, few physical barriers for faunal interchange existed among continental tetrapods during this period, and this should allow for refined biostratigraphic correlation of nonmarine Triassic strata. Many attempts have been made in recent years to use terrestrial vertebrates as index fossils for subdivision of the Late Triassic age (e.g., Lucas 1998); however, the recently proposed biochronologies are not supported by the co-occurrence of key taxa at some localities.

In the present paper, we describe the sedimentary facies and depositional systems of the Dockum Group, discuss the principle modes of occurrence of vertebrate fossils in these strata and critique their utility for biostratigraphic correlation. We focus attention primarily on five fossil vertebrate sites in the Dockum Group along the eastern escarpment of the High Plains in Texas, and illustrate several examples that typify the depostional setting of fossil vertebrate sites in these deposits.

\section{Stratigraphy}

Triassic strata of the Dockum basin are exposed along the eastern escarpment of the High Plains in Texas, and along the western escarpment of the High Plains and Pecos River valley in New Mexico (figures 1,2). These strata are contiguous beneath the Jurassic, Cretaceous, and Cenozoic cover of the High Plains, and may be physically traced from Texas to New Mexico in exposures through the Canadian River valley, which bisects the northern end of the basin (Schnable 1994). The Triassic strata were originally widely referred to as comprising the Dockum Group, but more recently have been designated by a varied and changing stratigraphic nomenclature (see reviews by Lucas et al 1985; Lehman 1992, 1994a, 1994b). Some authors have abandoned all attempts to subdivide these beds, or have used informal subdivisions such as 'upper' and 'lower' Dockum, which do not correspond to genetic subdivisions (McGowen et al 1979; Johns and Granata 1987). Others have reduced the Dockum to formation rank (e.g., Chatterjee 1986a). Recently, a variety of new stratigraphic names have been proposed for these strata on both the New Mexico and Texas sides of the High Plains (e.g., Lucas and Hunt 1989; Lucas and Anderson 1992). A simple consistent stratigraphic

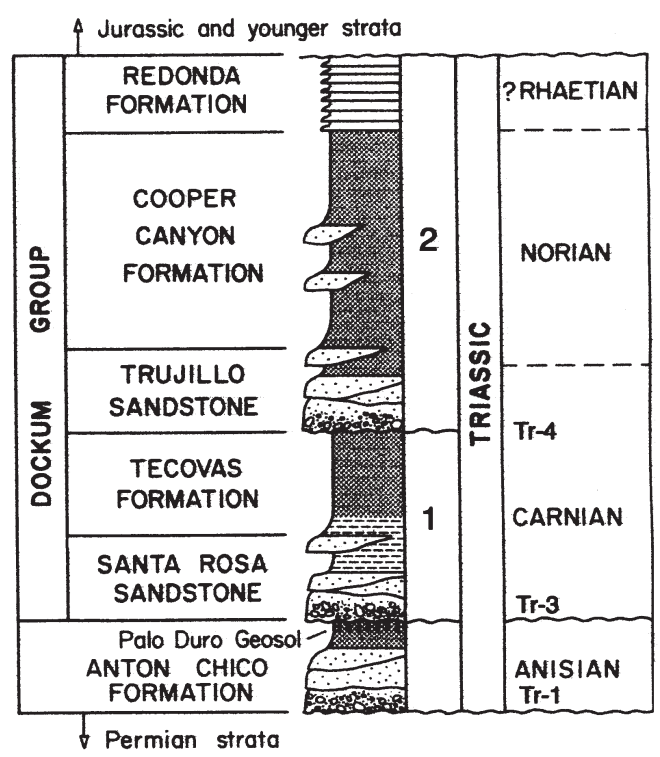

Figure 1. General stratigraphy of Triassic strata in the Dockum basin, showing depositional sequences 1 and 2 discussed in the text, and correlation with Triassic stages and principal unconformities (Tr-1, Tr-3, and Tr-4) recognized in the western United States by Pipringos and O'Sullivan (1978) and Lucas and Anderson (1993).

nomenclature for the Dockum Group was recently proposed by Lehman (1994a). The rationale for acceptance of this simple stratigraphy is explained elsewhere (Lehman 1994a, 1994b), and this nomenclature is used in the present study (figure 1).

The Dockum Group in its type area includes four mappable units: the Santa Rosa Sandstone, Tecovas Formation, Trujillo Sandstone, and Cooper Canyon Formation (figures 1, 2; Lehman 1994a, 1994b). These four units may be traced in outcrop and in the subsurface throughout nearly the entire extent of the Dockum basin. In eastern New Mexico, a fifth unit, the Redonda Formation, is included as the uppermost formation in the Dockum Group. The Redonda Formation is gradational eastward with the upper part of the Cooper Canyon Formation. An additional Triassic unit, the Anton Chico Formation, underlies the Dockum Group in eastern New Mexico. The Anton Chico and Redonda Formations are thus restricted in extent, and are not included in the present study.

Herein we focus attention exclusively on outcrops of the Dockum Group along the eastern escarpment of the High Plains in Texas, where the Santa Rosa, Tecovas, Trujillo, and Cooper Canyon Formations are exposed (figure 3). A full account of the depositional history of the entire Dockum basin will be given elsewhere, alongwith supporting data (Lehman et al, in prep.). The major events in Dockum depositional history were summarized by Lehman and Schnable (1992), and are reviewed below. 


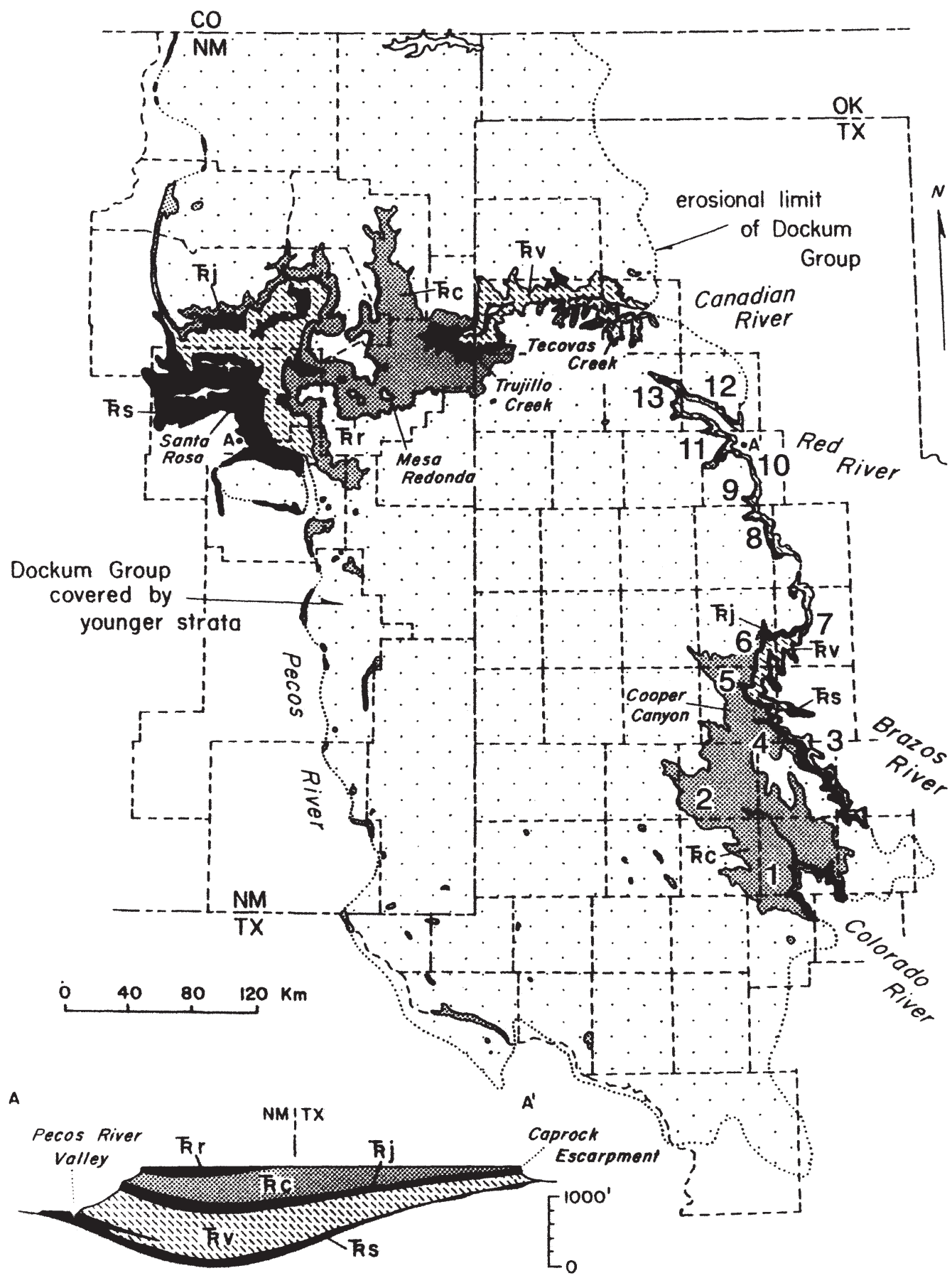

Figure 2. The Dockum basin of western Texas and eastern New Mexico, showing positions of stratigraphic sections 1 through 13 given in figure 3. Outcrop (dark patterns) and subsurface extent (light stipple) of Triassic strata in the Dockum basin are modified from Roth (1955), Dane and Bachman (1965), and McGowen et al (1979). Outcrop of Santa Rosa Sandstone (TR s), Tecovas Formation (TR v), Trujillo Sandstone (TR j), Cooper Canyon Formation (TR c), and Redonda Formation ( $\mathrm{TR} \mathrm{r}$ ) are shown, as are the locations of their type areas. Cross-section $\mathrm{A}-\mathrm{A}^{\prime}$ shows generalized subsurface relationships between the Triassic formations.

\section{Depositional systems}

Most earlier workers believed that strata filling the Dockum basin were entirely of fluvial origin. However, McGowen et al (1979, 1983) proposed that most of these Triassic strata consist of deltaic and lacustrine deposits, genetically related to the filling of a large lake basin that developed over the older Permian basin region. Although lacustrine deposits are indeed present in these strata, 


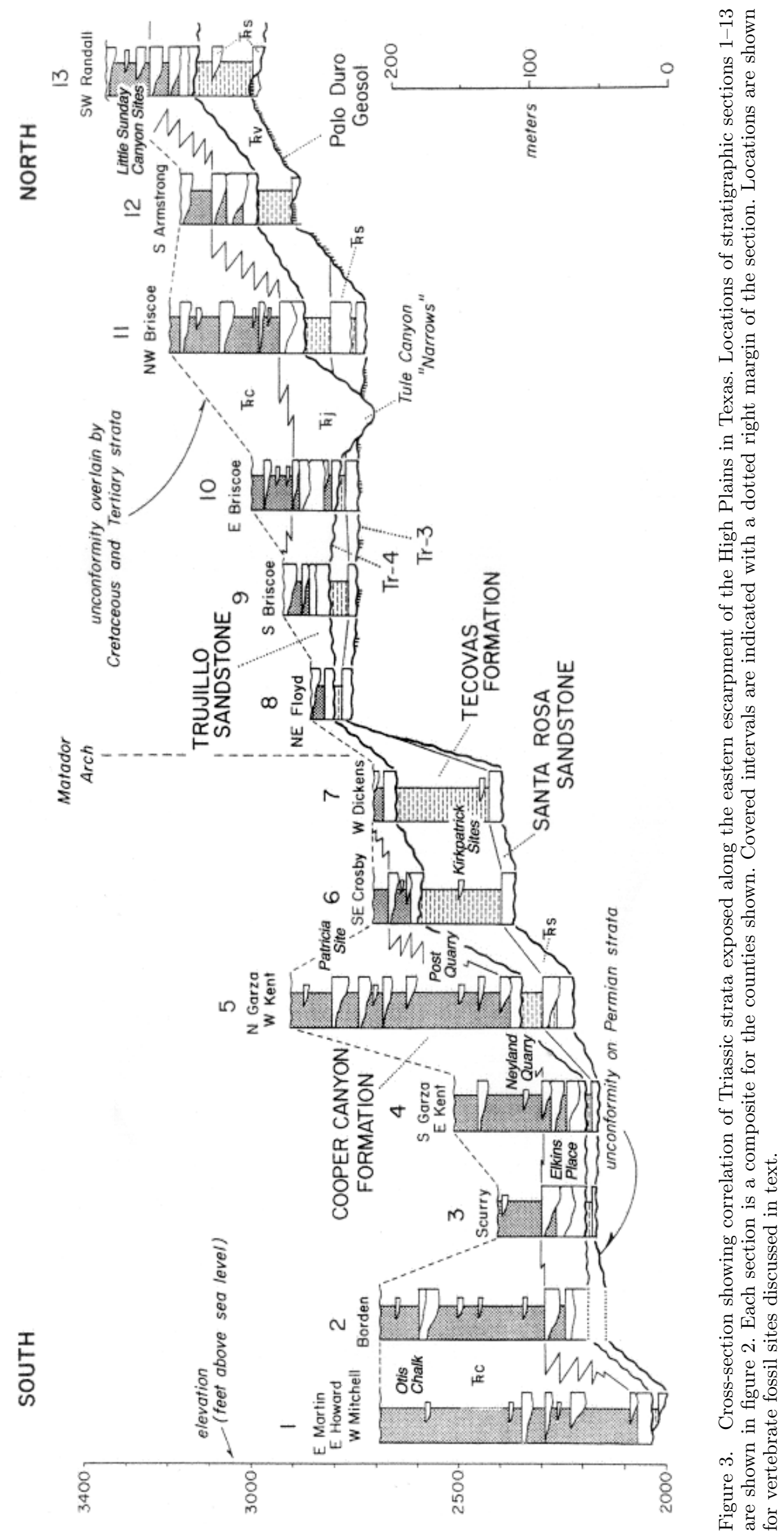


we have found that they are limited geographically and overemphasized in previous depositional models. Strata of the Dockum Group were deposited primarily by rivers.

Two alluvial depositional sequences are present in the Dockum exposures in Texas, represented by the 1) Santa Rosa-Tecovas, and 2) TrujilloCooper Canyon intervals (figure 3). The two sequences are separated by an unconformity (the 'Tr-4' unconformity of Pipringos and O'Sullivan 1978). Both depositional sequences generally fineupward, and have thick laterally-extensive fluvial channel sandstone units at their base. The basal fluvial channel sandstone units (Santa Rosa Sandstone and Trujillo Sandstone) are compound sandbodies reflecting multiple phases of channel incision, lateral migration, and aggradation. The basal channel sandstone-dominated part of each sequence grades upward with an increasing proportion of flood-plain mudstone, and locally lacustrine mudstone, such that the upper part of each sequence is instead mudstone-dominated (Tecovas and Cooper Canyon Formations). In the upper part of each depositional sequence, interbedded fluvial channel sandstone units are mostly single-storied and reflect single phases of channel migration and aggradation.

The Santa Rosa-Tecovas sequence is thin (less than $80 \mathrm{~m}$ ), and occupies a small part of the Dockum basin. It thins to the south, and is ultimately truncated at the base of the TrujilloCooper Canyon sequence (figure 3). Petrographic and paleocurrent data indicate that the Santa Rosa-Tecovas alluvium was derived mostly from the region north, northeast, and east of the present outcrop belt (e.g., Riggs et al 1996). The distinct, highly quartzose composition of this sediment indicates that the alluvium was likely derived through erosion of a highly weathered residual soil (the 'Palo Duro geosol' of Kanhalangsy 1997) that had previously developed over the region.

The Trujillo-Cooper Canyon sequence is thick (over $150 \mathrm{~m}$ ), extensive over the entire Dockum basin, and thins to the north (figure 3). This sequence rests with locally angular discordance on underlying strata. Sediment was derived from south-southeast of the present outcrop belt. The highly micaceous alluvium, with abundant metamorphic rock fragments indicate that the sediment was derived primarily from exposures of basement metamorphic rocks in the interior zone of the Ouachita orogenic belt (Long and Lehman 1993, 1994). This second episode of sedimentation resulted from significant tectonism and deep erosion to basement rocks, and accompanied rifting that would ultimately open the Gulf of Mexico.

The change in mineralogical composition, and presumed sediment source areas between the two
Dockum depositional sequences and the differences in paleocurrent orientations between them, indicate that these strata are the product of two distinct sediment dispersal systems. Such depositional sequences may be viewed as a response to episodes of tectonism, changes in climate, or base level changes induced by eustatic sea level fluctuations (e.g., Galloway 1989). Previous studies have concluded that the primary control on deposition in the Dockum basin was the base level change produced either by climate-controlled fluctuations in lake level (McGowen et al 1979), or by global sea level fluctuations (Lucas and Anderson 1992). Neither of these hypotheses, however, accounts for the dramatic shift in paleocurrent pattern and alluvial sediment mineralogy observed between the two depositional sequences. Base level or climate change alone would not result in a change in sediment source area. The regionally unconformable relationships between the depositional sequences, the change in location and magnitude of subsidence between sequences, and local evidence for intervening periods of deformation argue for a tectonic control on the origin of these depositional sequences, and are incompatible with their origin by climatic change or base level fluctuations alone.

\section{Sedimentary facies}

As in all fluvial deposits, strata of the Dockum Group can be broadly subdivided into two fundamental facies associations:

- coarse-grained channel-related facies that consist primarily of sandstone and conglomerate accumulated within and adjacent to stream channels in thalweg, bar, levee, and crevasse environments; and

- fine-grained overbank facies that consist primarily of siltstone and claystone accumulated in flood-plain environments.

Both the Santa Rosa Sandstone and Trujillo Sandstone are dominated by channel-related facies, whereas the Tecovas and Cooper Canyon Formations are dominated by flood-plain facies. Local lacustrine deposits also occur in both the Tecovas and Cooper Canyon Formations. The lacustrine deposits are nested within the fine-grained overbank facies, and appear to fill depressions of varied size that had formed on the flood-plain surfaces. Lacustrine sediments comprise a third typical facies association found in the Dockum Group.

Vertebrate fossil accumulations are found in all three of the facies associations. Several important fossiliferous sites are selected to show relationships between typical vertebrate bone assemblages in 


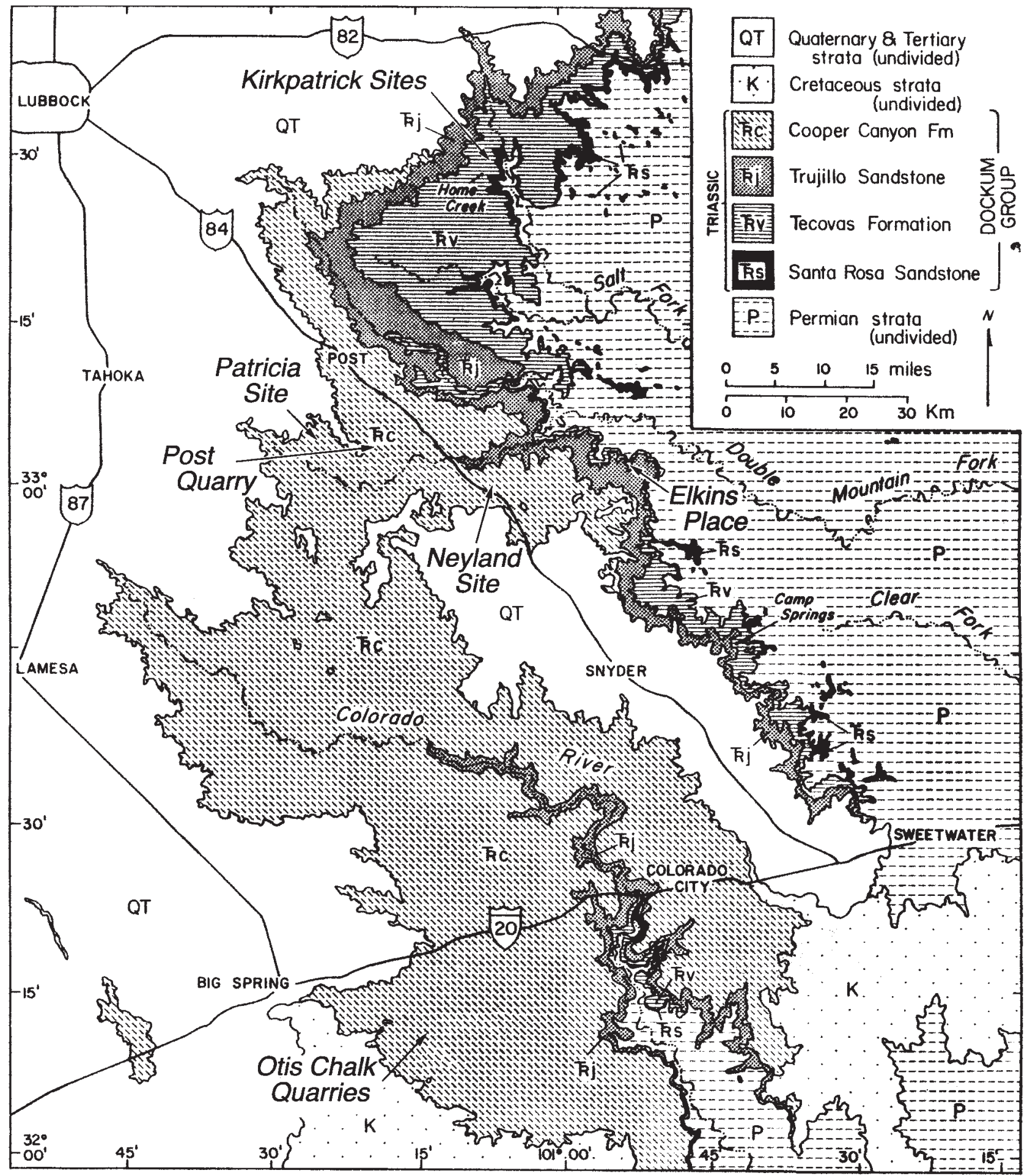

Figure 4. Generalized geologic map showing exposures of the Dockum Group strata in the Upper Brazos and Colorado River valleys, west Texas. The locations of several vertebrate fossil sites - Kirkpatrick Quarry, Patricia Site, Post Quarry, Neyland Site, and Otis Chalk Sites - are shown from north to south on this map (after Lehman 1994).

the Dockum and their depositional setting (figure 4). These fossiliferous sites, as seen from north to south, are: Kirkpatrick Quarry (Crosby County), Patricia Site, Post Quarry, and Neyland Site (Garza County), and Otis Chalk sites (Howard
County). Four of the fossiliferous sites, Patricia, Post, Neyland, and Otis Chalk are located in the Cooper Canyon Formation whereas the Kirkpatrick Quarry occurs in the Tecovas Formation (figure 4). 


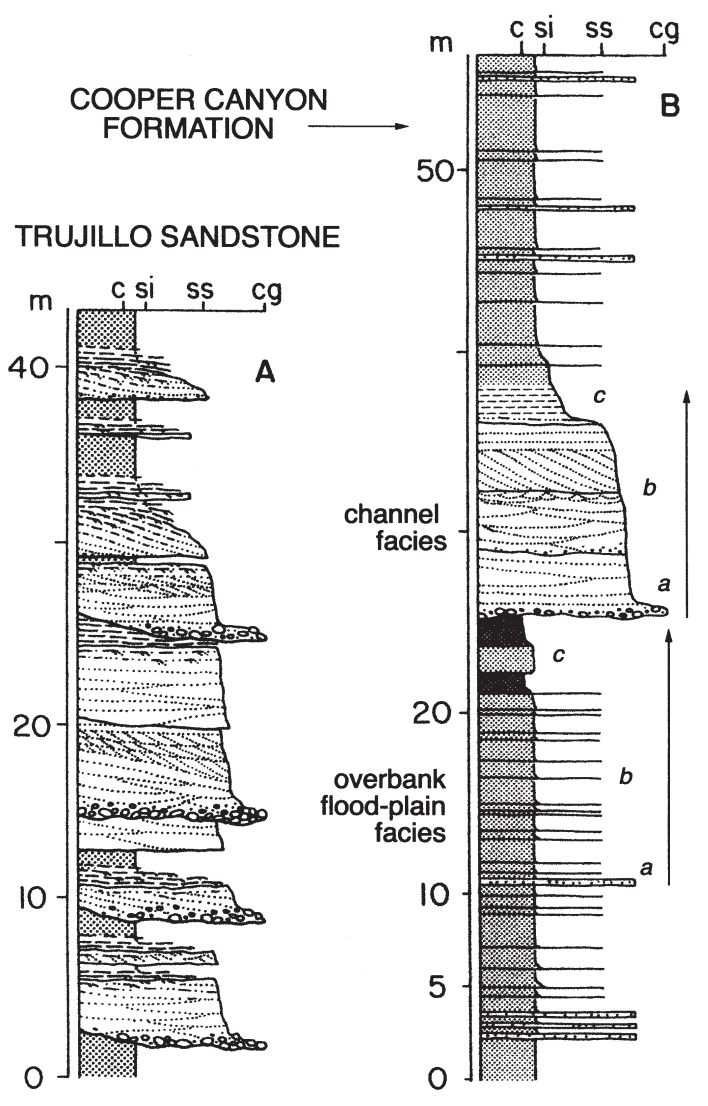

Figure 5. Typical sections of (A) the Trujillo Sandstone at the Silverton roadcut in Briscoe County (section 10 of figure 3), showing multiple sequences of fluvial channel aggradation, and (B) the upper part of the Cooper Canyon Formation near Justiceburg in Garza County (section 5 of figure 3; modified from Frelier 1987) showing predominance of fluvial overbank facies with typical sequence of (a) thin layers of carbonate nodule conglomerate, (b) laminated siltstone, and (c) massive red mudstone. Single phases of channel aggradation show a typical sequence with (a) horizontally bedded conglomerate, (b) parallel-laminated or cross-bedded sandstone, and (c) laminated or rippled siltstone. Scale is in meters, $\mathbf{c}=$ claystone, $\mathbf{s i}=$ siltstone, $\mathbf{s s}=$ sandstone, $\mathbf{c g}=$ conglomerate.

\subsection{Channel-related facies association}

Stream channel facies in the Dockum Group are similar to those described in many modern and ancient fluvial deposits (e.g., Allen 1965). Regardless of the original stream channel morphology (e.g., meandering or braided), the channel facies consists primarily of lenticular and sheetlike accumulations of sandstone and conglomerate in erosion-based fining-upward sequences (figure 5).

A typical vertical facies succession through the main body of the Santa Rosa Sandstone consists of an erosional surface overlain by horizontally bedded conglomerate, trough and tabular crossbedded sandstone, capped by parallel-laminated sandstone, ripple cross-laminated sandstone, and siltstone. Such deposits fine-upward, and typically comprise lenticular sandbodies that are arranged multilaterally (Fritz 1991). A typical section through the Santa Rosa Sandstone exhibits one or two such successions. Very little mudstone is present in the section, but the sandstone locally contains abundant carbonized wood and logs. These deposits record accumulation in braided bedload streams dominated by migrating transverse bars or sand flats. There is little evidence in these deposits for uniform lateral channel migration. The extensive cosets of tabular and trough cross-bedding resemble those produced by migration of mid-channel transverse bars in modern sandy braided streams such as the modern South Saskatchewan and Platte rivers (Smith 1970; Cant and Walker 1978). Similar facies occur in the overlying Tecovas Formation, but tend to be finer grained and less conglomeratic.

The typical vertical facies succession through the Trujillo Sandstone consists of an erosional surface overlain by (a) horizontally-bedded conglomerate, (b) massive sandstone, parallel-laminated sandstone, tabular or broad trough cross-bedded sandstone, and (c) ripple cross-laminated siltstone (figure 5A). Parallel-laminated sandstone dominates the facies succession in most areas. Striking lateral accretion surfaces are evident in many exposures (May 1988). A typical section through the Trujillo Sandstone may exhibit as few as three to as many as five or seven superimposed fining-upward cycles, reflecting multiple phases of stream channel incision, migration, and aggradation. Very little overbank flood-plain facies are interbedded in the lower part of the formation; however, in the upper part of the section, where the Trujillo is gradational with the overlying Cooper Canyon Formation, progressively more overbank facies are included, and the sandstones tend to be less conglomeratic, finer grained, and lenticular, representing primarily a single phase of channel migration (figure $5 \mathrm{~B}$ ). This stratigraphic trend suggests a gradual change from bedload or mixed-load streams, to suspended-load streams during aggradation of the major stream valleys. Similar facies successions are described in many modern and ancient meandering fluvial systems (e.g., Allen 1965). However, unlike many such systems, the Trujillo facies sequence is dominated by parallel-laminated sand deposited under upper flow regime conditions, with subordinate large and small scale cross-stratification. Allen (1984) modelled similar sequences as a result of relatively low channel sinuosity and fine bedload material. The Trujillo facies association resembles those produced in ephemeral streams with episodic shallow high-velocity flood events, such as those described by Sneh (1983), Stear (1983), Wells (1983), and Tunbridge (1984). 


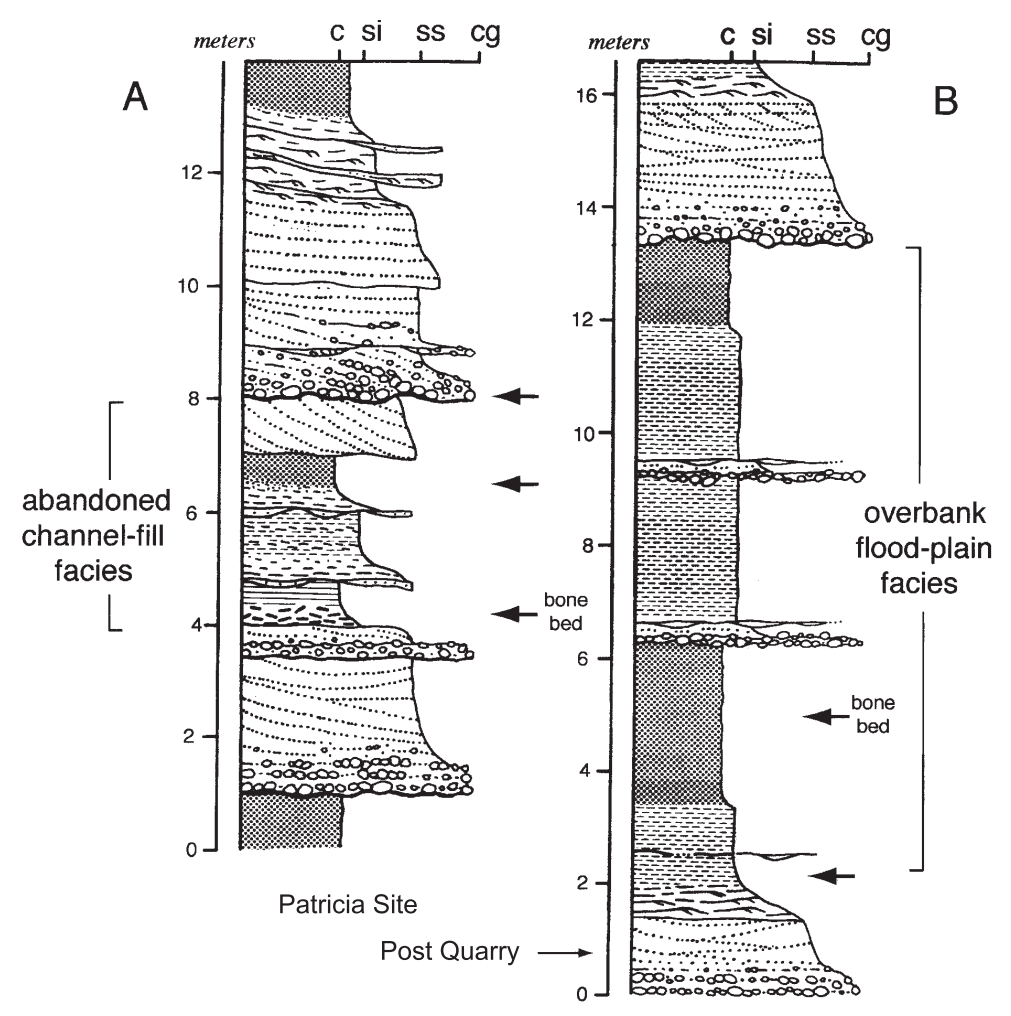

Figure 6. Examples of vertebrate fossil sites (A) associated with channel facies - the 'Patricia Site' in the upper part of the Cooper Canyon Formation (section 5 of figure 3 in Garza County); bones occur within abandoned channel-fill, overlain and underlain by typical channel facies, and (B) associated with overbank flood-plain facies - the 'Post Quarry' in the middle Cooper Canyon Formation (section 5 of figure 3 in Garza County); bone accumulations occur in the lower of two overbank aggradational cycles. Scale is in meters, $\mathbf{c}=$ claystone, $\mathbf{s i}=$ siltstone, $\mathbf{s s}=$ sandstone, $\mathbf{c g}=$ conglomerate. Arrows indicate levels of vertebrate fossil accumulations.

\section{1a Typical vertebrate bone assemblages}

Conglomeratic channel thalweg facies and crossstratified channel bar facies typically contain only isolated and abraded vertebrate skeletal elements, and isolated skulls that had been detached and transported away from the remainder of their carcasses prior to burial. Such remains comprise either elements transported away from carcasses that had disarticulated elsewhere, or relatively immobile lag elements that had resisted transport.

Apart from isolated transported specimens, channel facies locally contain densely concentrated pockets of autochthonous vertebrate remains. The 'Elkins Place Bone Bed' in Scurry County, described by Case (1932), and the recently discovered 'Patricia Site' in Garza County, are examples of vertebrate bone beds that occur in channel facies, and reflect autochthonous concentrated skeletal accumulations. In these cases, the bones occur in local beds of coarse clay gall conglomerate or in restricted lenses of gray/green mudstone with abundant carbonized plant material within channel facies (figure 6A). These deposits appear to represent the fill of abandoned stream channels where local quiescent bodies of standing water formed. Such environments may have been preferentially inhabited by aquatic and semi-aquatic animals, and more conducive to preservation of their remains than the energetic environments of active stream channels.

Vertebrate remains in channel facies are found in all states of preservation from isolated single bones, to disarticulated associated partial skeletons, to nearly complete skeletons. The bones in many cases are preserved 'in the round' without severe distortion or crushing by compaction, nor are they covered in concretion, as is typical of bones found in fine-grained flood-plain and lacustrine facies. Channel facies typically sample an aquatic or semiaquatic habitat. Bone accumulations in channel facies are typically dominated by aquatic tetrapods such as metoposaurs (e.g., 'Elkins Place Bone Bed') or phytosaurs (e.g., 'Patricia Site').

The 'Patricia Site' was discovered in 1998 by Douglas Cunningham, a volunteer at the Museum of Texas Tech University (figure 7A). The site is located about $15 \mathrm{~km}$ south of Post, in Garza County (figure 4). Vertebrate fossils occur here in channel deposits of fine-grained sandstone and 
green mudstone within the uppermost part of the Cooper Canyon Formation. The most abundant fossils collected from this site are phytosaurs including four exquisite skulls of highly derived Pseudopalatus and Redondasaurus. Several articulated or partially associated phytosaur skeletons have been identified at this site.

\subsection{Overbank flood-plain facies association}

Flood-plain facies in the Dockum Group are similar to those described in many modern and ancient fluvial successions (McKee et al 1967). Thick accumulations of overbank facies are typically associated with sinuous meandering stream systems that carry a high suspended sediment load (e.g., Allen 1965). The upper part of the Tecovas Formation (the 'magenta shales' of Gould 1907), and much of the Cooper Canyon Formation consist of red siltstone and mudstone interpreted as overbank flood-plain deposits (figure 5B). Local lenses and sheet-like layers of sandstone are interbedded within the dominantly fine-grained deposits. These local sandstone beds are comparable in lithology and facies to those of the Santa Rosa or Trujillo Sandstone but are not generally as thick or as extensive laterally. A typical vertical facies succession in the overbank deposits consists of (a) thin sheet-like or channelized beds of reworked pedogenic 'caliche' nodule conglomerate ('lime pellet rock' of Chatterjee 1985), overlain by (b) thinly laminated siltstone in gently dipping overlapping sets, capped by (c) massive red mudstone with carbonate nodules (figure 5B). The caliche granule lag deposits form the base of a typical flood-plain facies succession, and appear to rest on depressions produced during episodes of erosional degradation of the flood-plain surface. The overlying laminated siltstone fills the depressions concordantly in gently inclined continuous beds lacking evidence for episodic reactivation. Successive flood-plain accretionary deposits are separated by slight angular discordances. Such 'paleo-gully fill' sequences likely record the periodic erosional incision and subsequent aggradation of tributary drainages on the flood-plain surfaces (figure 10; Frelier 1987). Similar deposits are found in the Triassic Chinle Formation of Arizona (Kraus and Bown 1986).

Whereas most modern and many ancient overbank flood-plain deposits are extensively bioturbated, resulting in crude massive bedding, those of the Dockum Group tend to retain well-preserved primary depositional structures. Only the finer grained red mudstone deposits that cap each floodplain succession are structureless. These have a crude blocky texture with scattered pale green reduction spots or 'haloes'. The mudstone consists of mixed layered smectite-illite, quartz, and muscovite; many examples are highly micaceous (May 1988; May and Lehman 1989). The abundance of mica, mixed layer clays and smectite indicates that the flood-plain sediments were not subject to prolonged weathering and leaching in spite of the tropical paleolatitude of the Dockum basin during Triassic time. Their striking red coloration suggests accumulation under highly oxidizing conditions. The flood-plain mudstone also contains scattered small interstitial carbonate nodules of pedogenic origin ('caliche') indicative of a semi-arid or subhumid climate. The retention of primary stratification suggests that the bulk of overbank sediment accumulation took place either too rapidly or too frequently to allow for extensive colonization of the flood-plain surfaces, or under conditions that were generally too hostile for growth of dense vegetation. Perhaps rapid deposition of each thick floodplain succession occurred under flood conditions, and only the uppermost part of each sequence was later disturbed by establishment of vegetation during periods of flood-plain stability.

Alternatively, flood-plain environments might have been generally hostile, perhaps arid, and this inhibited the growth of vegetation. Unlike correlative deposits of the Chinle Formation in Arizona, the channel and overbank deposits of the Dockum Group do not contain significant accumulations of fossil logs. Although petrified wood is locally abundant in some stream channel and lacustrine deposits of the Dockum, large trunks are usually not observed. However, the general paucity of petrified logs in the Dockum might also be attributed to a preservational artifact. In Arizona, the Chinle Group sediments contain voluminous volcanic detritus. Devitrification of ash in the sediments may have allowed for ready silicification of buried logs. In contrast, the volcanic component in Dockum sediments is appreciably small. As a result, tree trunks may not have been subject to permineralization after burial. A 'petrified forest' in the Cooper Canyon Formation near Justiceburg provides some information on the structure of vegetation on Dockum flood-plains. About fifty closely spaced upright tree trunks are found at this locality. The great majority of the trees belong to Araucarioxylon. Much of the vegetation may have been restricted to the riparian corridor in and adjacent to stream channels where there was a perennial source of water.

\section{2a Typical vertebrate bone assemblages}

Both the 'Post Quarry' of Chatterjee (1985), and the 'Otis Chalk' localities (Gregory 1945; Elder 1978) exemplify vertebrate fossil assemblages that 
accumulated primarily in flood-plain facies (figure $6 \mathrm{~B})$. The bone-bearing deposits at these sites consist primarily of massive jointed red mudstone with blocky, columnar, or prismatic structure and poor stratification (the uppermost unit $\mathrm{c}$ in the typical overbank flood-plain sequence described above). The irregular curved joint surfaces in the mudstone are coated with clay and/or manganese oxides, and show slickensides. The bones are in many cases also distorted or crushed by compaction of the mudstone and broken along smooth fractures by joints in the clay, and are variably coated in calcareous or iron oxide concretion. Isolated vertebrate remains are encountered as scattered elements throughout these deposits; however, in places the bones are concentrated in local 'pockets' that have been sites of productive quarrying efforts.

The origin of these 'pockets' with high bone concentration has been a matter of speculation. A mass mortality event resulting from overbank flooding is sometimes called upon to explain these pockets, especially such multi-species bone beds as Post Quarry (e.g., Chatterjee 1985). However, the usual disarticulated but associated condition of many skeletons and vague or marked current alignment of bone long axes suggests that some other longer term process of bone concentration was responsible for the initial accumulation and later dispersion of the carcasses. The vertebrate remains are variably preserved as articulated skeletons, partly articulated segments of skeletons, or associated but disarticulated skeletons. Such sites often preserve small and delicate skeletal elements along with larger and more durable elements, that together do not constitute an assemblage of hydraulically equivalent objects. Hence, neither concentration nor winnowing of carcasses by current action seems a likely mechanism for the resulting assemblages. Such sites sample primarily terrestrial habitats, and yield a diverse assemblage of trilophosaurs, aetosaurs, rauisuchids, and dinosaurs that differ from the typical metoposaur and/or phytosaur dominated assemblages found in channel-related or lacustrine facies.

The 'Post Quarry' was discovered in the 1970s by an amateur fossil collector who found a partial skull of a phytosaur exposed in a conspicuous conical red hill at the edge of the caprock, $16 \mathrm{~km}$ southeast of Post, in Garza County (figures 4, 6B, 7B). Later, extensive collecting at the Post Quarry began in 1980 by Chatterjee and his students. This site was later included in the type section of the Cooper Canyon Formation of the Dockum Group (Chatterjee 1986a; Lehman et al 1992). The vertebrate fossils occur in a $30-\mathrm{cm}$ thick flood-plain mudstone unit of the Cooper Canyon Formation.
The bone bed occurs lower in the Cooper Canyon Formation relative to the Patricia Site. The quarry has produced a prolific array of tetrapods in a single dense layer, including two small temnospondyl amphibians, Apachesaurus (Davidow-Henry 1993; Hunt 1993) and Rileymillerus (Bolt and Chatterjee 2000); a tritheledontid cynodont, Pachygenelus (Chatterjee 1983); a dicynodont, Placerias; two rauisuchids, Postosuchus (Chatterjee 1985) and Chatterjeea (Long and Murry 1995); a phytosaur, Leptosuchus; three stagonopedids, Typothorax, Paratypothorax, and Desmatosuchus (Small 1989); a theropod, Shuvosaurus (Chatterjee 1993); an ornithischian, Technosaurus (Chatterjee 1984); and a primitive bird, Protoavis (Chatterjee 1991). The Post Quarry represents a concentration of caracasses, possibly resulting from a period of mass mortality. The fauna preserved here consists primarily of terrestrial animals.

The classical 'Otis Chalk' localities occur $25 \mathrm{~km}$ southeast of Big Spring near Otis Chalk, in Howard County (figure 6). Here the tetrapod fossils also occur in a typical overbank red mudstone unit within the Cooper Canyon Formation (figure 7C). The stratigraphic position and implications of the Otis Chalk fauna have been a subject of debate in recent years (see discussion below). Vertebrate fossil collections from the Otis Chalk area were initially made by J W Stovall for the University of Oklahoma in 1931. An extensive collection effort was undertaken from 1939 to 1941 by the crews of the Works Projects Administration (WPA), under the direction of Grayson Meade for the University of Texas at Austin in 1939. Elder (1978) described the paleontology and taphonomy of these quarries. Important vertebrate fossils from these quarries include a temnospondyl amphibian, Buettneria; an archosauromorph, Trilophosaurus (Gregory 1945); a prolacertiform, Malerisaurus (Chatterjee 1986b); a doubtful rhynchosaur, Otischalkia (Elder 1978; Hunt and Lucas 1991a); two phytosaurs, Paleorhinus and Rutiodon (Gregory 1962); two stagonolepidids, Longosuchus, (Sawin 1947; Hunt and Lucas 1990) and Desmatosuchus (Long and Murry 1995); and four rauisuchids, Poposaurus, Postosuchus, Lythrosuchus, and Chatterjeea (Long and Murry 1995).

\subsection{Lacustrine facies association}

The lower part of the Tecovas Formation (the 'variegated shales' of Gould 1907) is gradational and intertonguing with the upper part of the Santa Rosa Sandstone and are genetically related to deposition in lacustrine and deltaic environments. The lower part of the Tecovas records significant lacustrine deposition in numerous small lakes and 


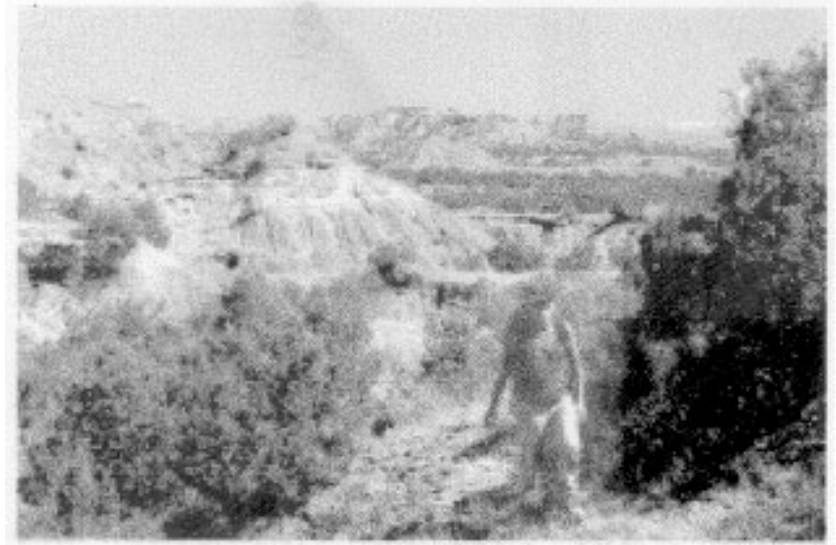

A

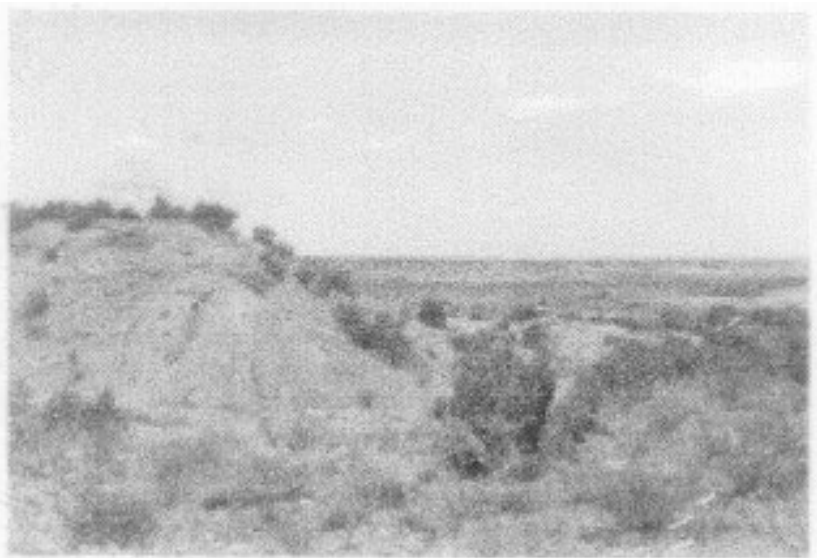

C

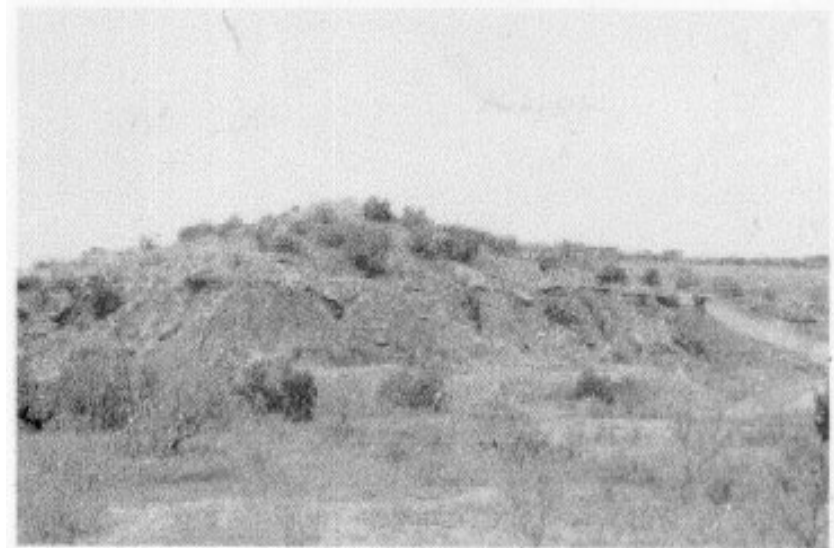

B

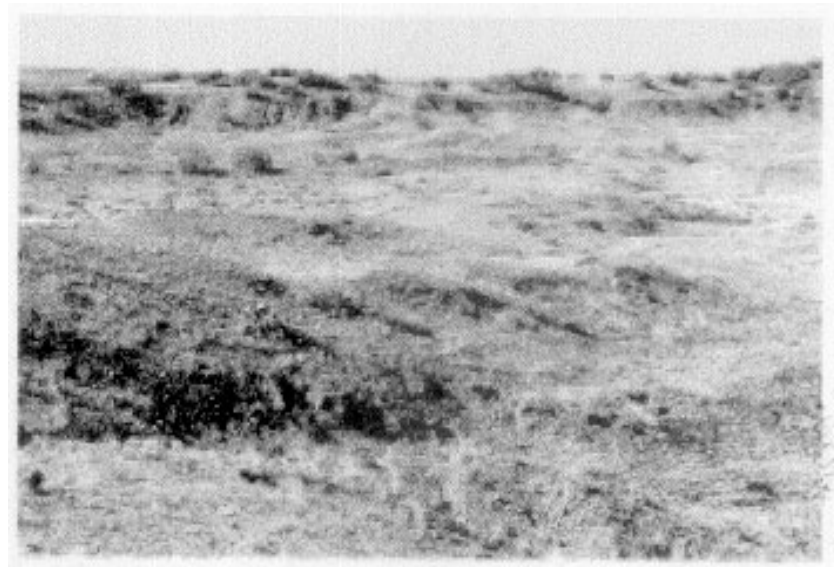

D

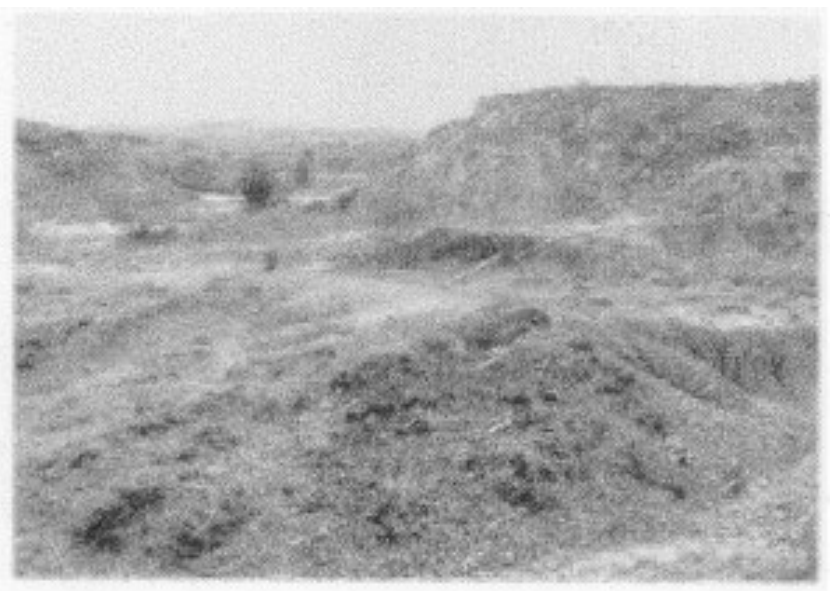

$\mathrm{E}$

Figure 7. Views of various vertebrate fossil sites in the Dockum Group (see figure 6 for locations). (A) Patricia Site, Garza Co; (B) Post Quarry, Garza Co; (C) Otis Chalk Site, Howard Co; (D) Neyland Site, Garza Co; (E) Kirkpatrick Site, Crosby Co.

ponds, and in associated fluvial channel and overbank environments (Fritz 1991). The lacustrine deposits comprise distinctive drab yellow, green, and gray-green claystone beds composed largely of smectite (Na-smectite) with lesser amounts of illite and kaolinite, and interspersed nodules of 


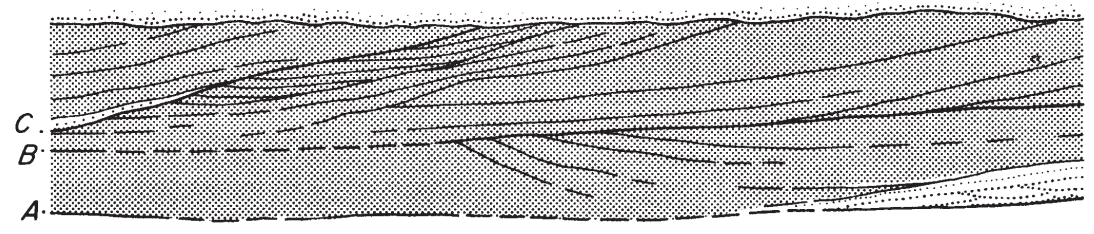

overbank flood-plain aggradational sequences

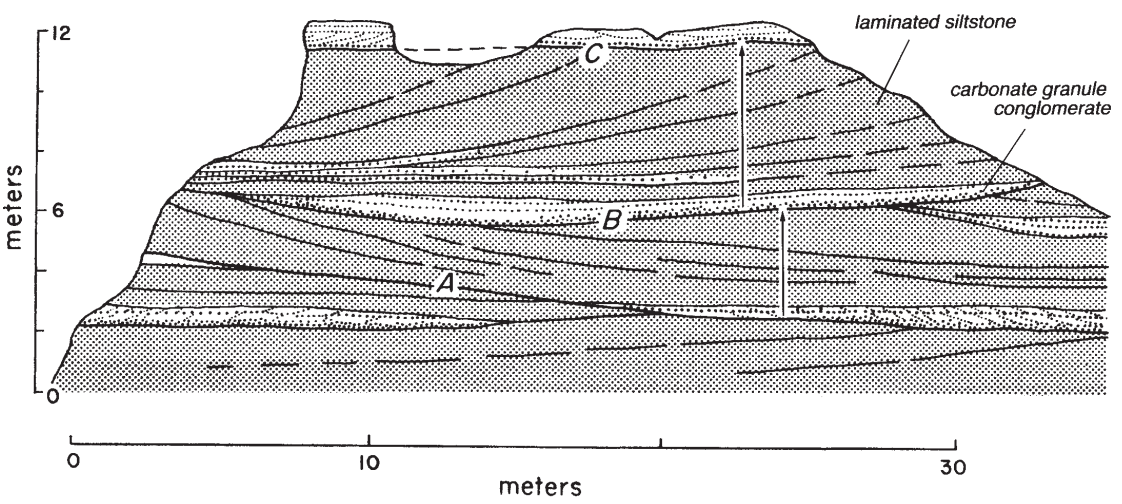

Figure 8. Outcrop drawings of typical flood-plain aggradational sequences in overbank facies, showing truncated sets (A, B, and C) of inclined bedding in fine-grained facies of the Trujillo Sandstone (above) in Palo Duro Canyon, Randall County (section 13 of figure 3) and the Cooper Canyon Formation (below) in Garza County (section 4 of figure 3: modified from Frelier 1987). Each section shows at least three sets of inclined bedding (A, B, C) in thinly laminated siltstone, separated by erosional discontinuities lined with carbonate granule conglomerate and unionid bivalve shells. Arrows indicate typical aggradational cycles.

calcite, dolomite, and ankerite (May 1988). Analcite also occurs in the drab yellow and green claystone beds. The lacustrine beds contain a variety of burrows, coprolites, fresh water molluscs, and ostracods (e.g., Kietzke and Lucas 1991; Murry 1989). Dense accumulations of whole, articulated, unionid bivalves are found in some of these deposits. In Texas, lacustrine facies are thickest and most extensive in the vicinity of Palo Duro Canyon in Randall County. Elsewhere, these deposits occur only as lenses of limited aerial extent. In good exposures, such deposits are seen to occupy subcircular or elongate depressions of varying size. Several well-exposed examples show multiple phases of basin development separated by slight angular discordances (figure 9). Similar ancient lacustrine deposits have been described by High and Picard (1965), Dubiel (1987), Allen (1981), Boone (1979) and Turner and Fishman (1991). The Lake Eyre basin of Australia may be a modern analog (Bonython and Mason 1953). Lacustrine deposits also occur in the correlative Triassic Newark Supergroup along the Atlantic Coastal Plain in North America, however, these deposits apparently resulted from sedimentation in much larger, deeper, stratified perennial lakes (e.g., Suchecki et al 1988; Olsen 1990).

The Dockum lacustrine facies association has a typical sequence with (a) beds of ripple cross-laminated and parallel-laminated very fine sandstone, and (b) thinly laminated red siltstone, resting on (c) carbonate granule conglomerate, and overlain by (d) massive dark red mudstone (figure 9). These lithofacies are similar to those typically found in the overbank flood-plain facies but interfinger with (e) gray-green claystone with carbonized plant material, coprolites, and remains of aquatic invertebrates, or (f) tan-yellow claystone with carbonate-filled (?lungfish) burrows. Together, all six lithofacies are observed to dip centripetally into broad depressions, and show penecontemporaneous deformation (soft-sediment folding and faulting). In some cases, the carbonate granule conglomerate fills both small scale mud cracks and much larger 'megacracks' within the lacustrine mudstone, suggesting that the lake floors were occasionally desiccated. However, the drab gray-green claystone that typically fills the central parts of these peculiar lacustrine depressions indicates that perennial subaqueous stagnant water conditions also prevailed at times. The very finegrained sediment, its drab coloration, high organic matter content, and aquatic vertebrate and invertebrate fauna indicate that the depressions held standing water for extended periods of time, and that the water remained fresh enough that evaporite minerals did not normally precipitate.

Depending on the extent of exposures, beds dipping at varied angles are evident in the lacustrine deposits, some very steeply inclined (beyond the 

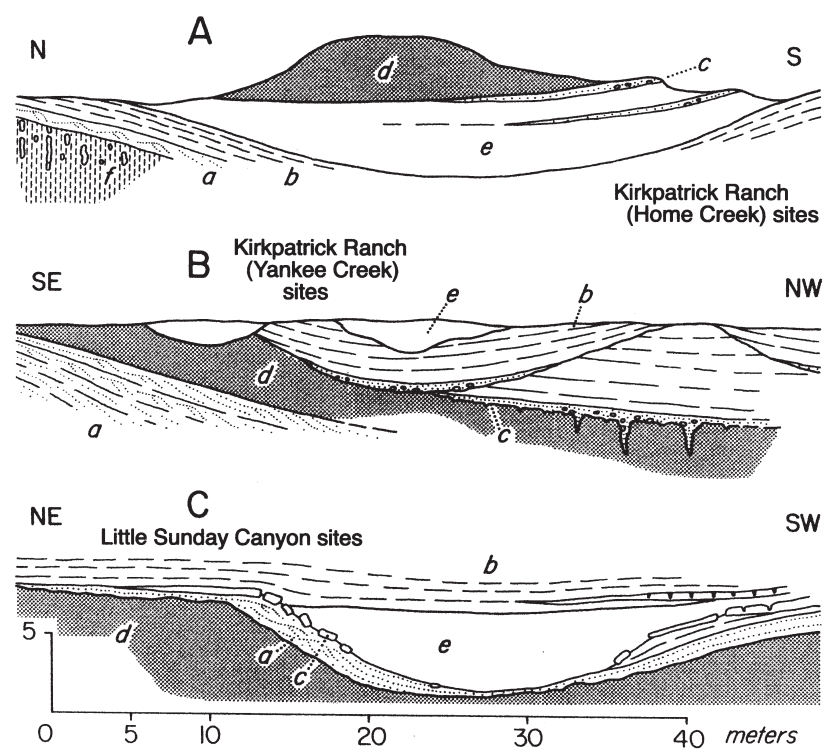

Figure 9. Examples of small flood-plain lacustrine basin morphology, showing distribution of characteristic facies: (a) very fine ripple cross-laminated and parallel-laminated sandstone, (b) thinly bedded red siltstone, (c) carbonate granule conglomerate with unionid bivalves and vertebrate bones, (d) massive dark red mudstone, (e) green-gray claystone with coprolites, (f) tan-yellow mudstone with carbonate filled burrows. Generalized cross-sections are from (A) the lower Tecovas Formation 'Kirkpatrick Ranch Sites' on Home Creek in Crosby County (section 6 of figure 3); and (B) the lower Cooper Canyon Formation 'Kirkpatrick Ranch Sites' in Crosby County (section 6 of figure 3) and (C) the Cooper Canyon Formation 'Little Sunday Canyon' sites in Randall County (section 13 of figure 3). Lake margin sediments in (C) contain redeposited cemented lithoclasts of unionid bivalve/carbonate granule conglomerate.

normal angle of repose). These zones of dipping strata define small basins floored by the distinctive well-sorted carbonate granule conglomerate, often with abundant unionid bivalve shells (figures 10, 11). McGowen et al (1979) identified these dipping strata as deltaic foreset beds. However, the inclination of these strata is highly variable over a small area, and locally very steep (up to 60 degrees, figure 9). Their dip direction is also at high angles to local paleocurrent directions, and the sets rest on erosional surfaces floored by well sorted carbonate granule conglomerate exclusively of local derivation. The strata are not gradational with underlying deposits, as would be expected if these were progradational deltaic foreset beds. We regard these dipping strata as the penecontemporaneously deformed lacustrine fill of flood-plain depressions.

Thin successions of current ripple crosslaminated sandstone, interbedded with the lacustrine mudstone, exhibit syndepositional deformation, and conspicuous local angular relationships. The abundant soft sediment deformation, slumping, and faulting of lake margin strata probably resulted from loading of deltaic sands on water-saturated lacustrine clay during progradation of the lake margins. Significant soft sediment deformation, syndepositional slumping, and local angular relationships are particularly striking within the lacustrine strata of the Tecovas Formation (e.g., Fritz 1991). We suggest that these units owe their origin to localized syndepositional subsidence of the flood-plain surfaces. Local areas of subsidence may have been induced by dissolution of Permian evaporite deposits that underlie the Dockum Group. This mechanism is widely believed to be responsible for Tertiary and Quaternary lacustrine basins found in strata overlying the Dockum Group of the High Plains (e.g., Reeves 1990). Similar deformation is observed in the Tertiary and Quaternary lake deposits of the High Plains region, where differential subsidence in response to dissolution of underlying Permian salt beds is thought to be responsible for the deformation (Caran and Baumgardner 1986; Wilson 1988; Reeves 1990). The same process may have been operative during Triassic time.

\section{3a Typical vertebrate bone assemblages}

Many of the prolific vertebrate fossil sites in the Dockum Group occur within, or closely associated with, lacustrine facies. Well-known localities such as those at 'Kirkpatrick Ranch' (figure 9A; the 'Walker's Tank' localities of Case 1928 and 'Kalgary' or 'Home Creek' localities of other authors, e.g., Murry 1989), and at 'Kirkpatrick Quarry' (figure 9B; the 'Cedar Mountain' localities of Case 1928), and 'Little Sunday Canyon' (figure 9C) exemplify the relationships observed in the lacustrine facies association.

Vertebrate fossil accumulations are found in the coarse carbonate granule layers, as well as within the lacustrine mudstone, and in surrounding overbank flood-plain deposits that interfinger with the lacustrine facies (figure 10). The granular lag deposits of reworked pedogenic carbonate nodules in many places contain concentrations of vertebrate teeth and isolated abraded bones. These 'micro-vertebrate' assemblages yield diverse aquatic and terrestrial faunal assemblages, such as those studied in detail by Murry (1989). The lacustrine mudstone and interfingering flood-plain deposits preserve isolated vertebrate bones as well as bone-beds of associated and articulated skeletons. These assemblages are dominated by aquatic and semi-aquatic organisms.

The 'Neyland Site' exemplifies vertebrate fossil accumulations in the varied lithofacies associated with these peculiar lacustrine basins. Father Malcolm Neyland, a local catholic priest and a 


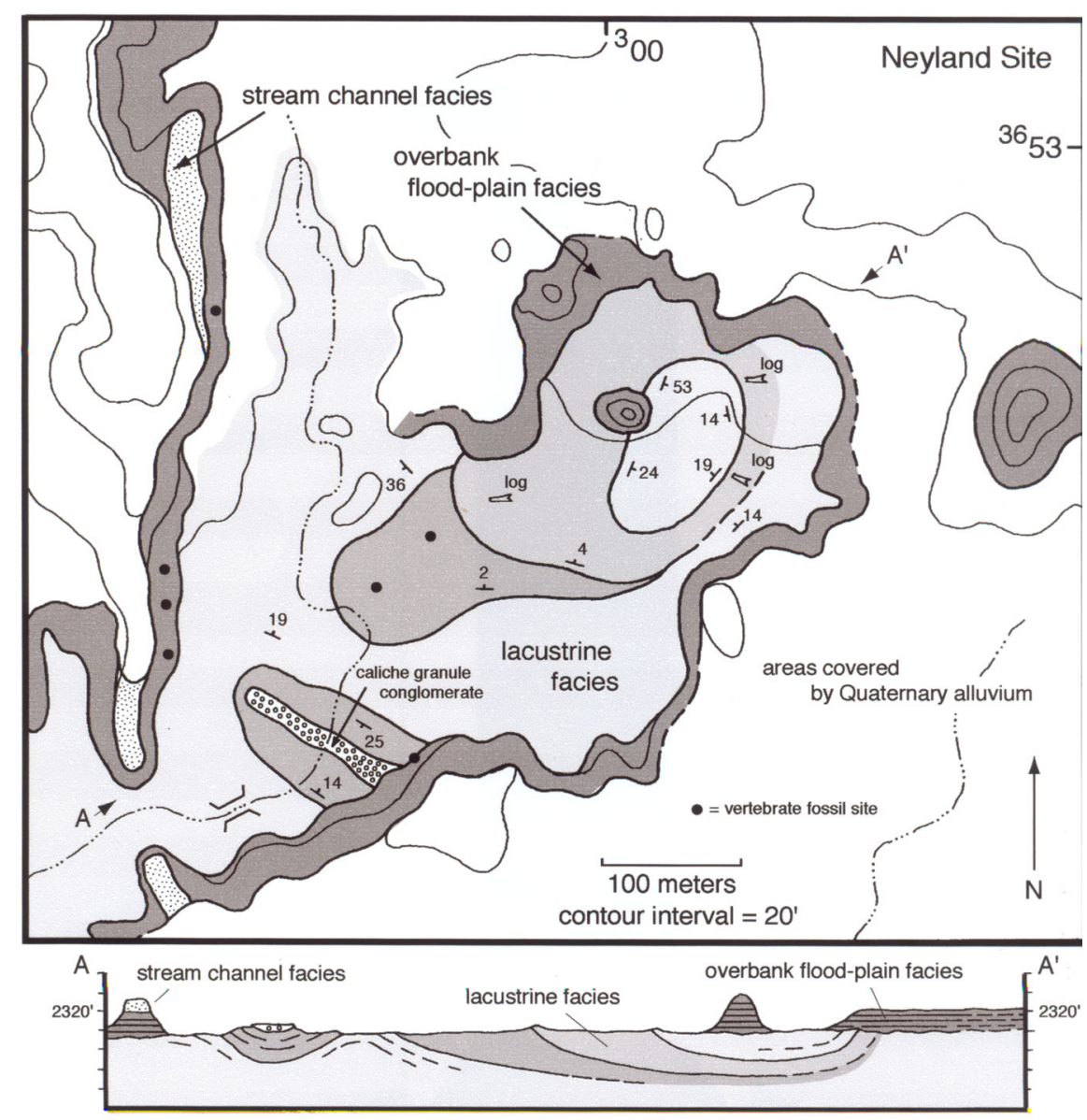

Figure 10. Map and cross-section showing the stratigraphic relationships in a typical lacustrine facies association at the 'Neyland Quarry' in Garza County (section 4 of figure 3). Four successive intervals of deformed, centripetally dipping lacustrine strata fill a depression, and are overlain disconformably by overbank flood-plain facies. An exhumed stream channel deposit caps the section along the western border of the map area. Vertebrate fossils occur in all facies; significant collections were made at the sites indicated.

volunteer at the Museum of Texas Tech University, discovered this site in 1986 (figures $7 \mathrm{D}, 10$ ). It is located near Justiceburg, in Garza County (figure 6). The fossiliferous horizon occurs lower in the section of the Cooper Canyon Formation relative to both the Post Quarry and Patricia Site. Lacustrine mudstone, flood-plain mudstone, and carbonate granule conglomerates are all rich in vertebrate remains. A flood-plain mudstone bed has yielded associated skeletons of large tetrapods such as the temnospondyl Buettneria, the primitive phytosaur Paleorhinus (Simpson 1998), a new dicynodont yet to be described (Edler 1999), as well as several smaller vertebrates. The carbonate granule layers are rich in dissociated remains of small vertebrates, and skeletons of trilophosaurids, Malerisaurus, and Protoavis have been collected. Petrified wood is also common, preserved as fallen $\log$ 'jams'.

The 'Kirkpatrick Quarry' occurs in the Tecovas. This site was found by Chatterjee and his students in 1982. It occurs $12 \mathrm{~km}$ southwest of Crosbyton in Crosby County (figures 4, 7E, 9B). Microvertebrates are concentrated here in a thin layer of carbonate granule conglomerate within the fill of a lacustine basin. The bones are disarticulated but well-preserved. Various taxa including fish (Ceratodus, Semionotus, Xenacanthus); two temnopondyls, Buettneria and Apachesaurus; a sphenodontid, Clevosaurus; procolophonids; the primitive bird, Protoavis; and several unidentified species have been collected from this granule bed.

\section{Tetrapod diversity}

The Dockum tetrapod fauna represents one of the finest and most diverse Late Triassic continental assemblages found anywhere in the world. The Museum of Texas Tech University (TTU) holds a significant collection of these Dockum tetrapods; most of the discussions in the text are based on the 

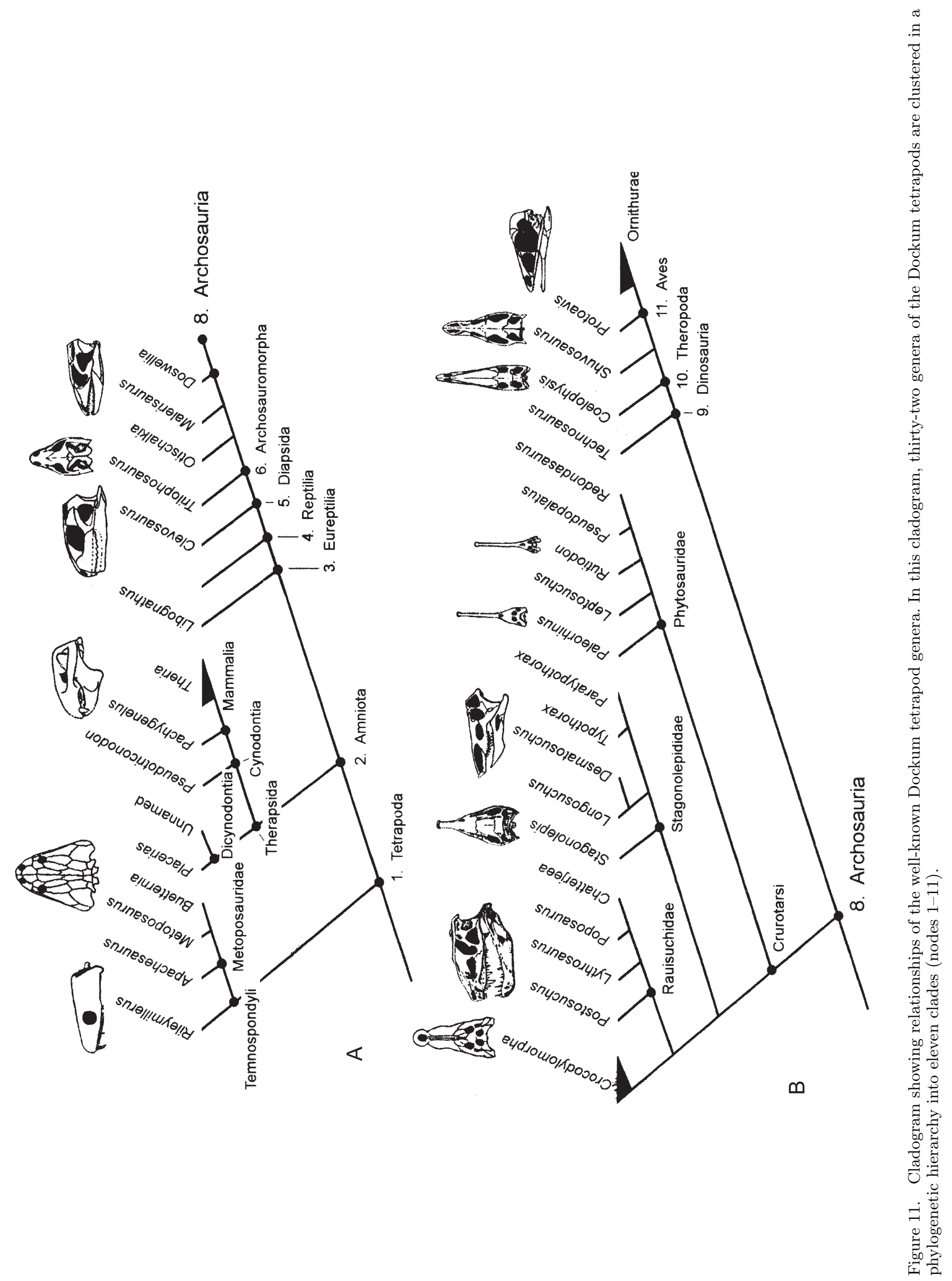
TTU collection. These specimens were collected mainly from the Tecovas and Cooper Canyon Formations. Unlike tetrapods, fish remains are sparse, and consist primarily of the tooth-bearing elements of sharks, actinopterygians, lungfish, and coelacanths. In our discussion, we have concentrated on the tetrapods only, as they are better represented, easily identified, and useful for biostratigraphic correlation. Major groups of these tetrapods are discussed briefly in a phylogenetic hierarchy (figure 11) and their stratigraphic ranges are discussed. Eleven important clades of tetrapods have been identified in the Dockum fauna, following the broad phylogenic scheme of Benton (1997).

\section{Node 1. Tetrapoda: Amphibia: Temnospondyli}

Four taxa of temnospondyl amphibians are currently known from the Dockum. Rileymillerus is a small animal represented by an exquisite skull, about $35 \mathrm{~mm}$ long, and a string of vertebrae (Bolt and Chatterjee 2000). It was a small terrestrial animal, probably insectivorous. Both the skull and postcranial skeleton were collected from the Cooper Canyon Formation at the Post Quarry. Its affinity with other temnospondyls is uncertain. Rileymillerus superficially resembles in size and proportion the poorly preserved specimen Latiscopus from the coeval Otis Chalk Quarry (Wilson 1948), the latter is considered nomen dubium.

The remaining three taxa, Apachesaurus, Metoposaurus, and Buetternia, belong to the family Metoposauridae. Metoposaurs were large aquatic amphibians, distinguished by their flat skulls and the position of the orbits rostral to the midlength of the skull table. Bones of the skull roof are deeply sculptured on their dorsal surfaces. Metoposaurs are recorded from the Late Triassic deposits of North America, Germany, North Africa, and India. Apachesaurus (Hunt 1993, Davidow-Henry 1989), a small metoposaur (skull length 73-164 mm) has a distinctive shallow otic notch and is known both from the Tecovas and Cooper Canyon. Metoposaurus and Buetternia are very similar in size and morphology and often they are synonymized, although the former name has priority (Roy Chowdhury 1965). However, Hunt (1993) differentiated Metoposaurus from Buettneria on the basis of the exclusion of the lacrimal from the orbit in the former genus. Buetternia is the most abundant metoposaurid in the Tecovas Formation, where the most commonly preserved bones are heavy elements, such as the skull, clavicle, and interclavicle. It also occurs sporadically in the Cooper Canyon Formation. The largest skull in the TTU collection is $640 \mathrm{~mm}$ long. Metoposaurus is represented by several skulls and skeletons from the Elkins
Place Bonebed in Scurry County (Case 1932). The taxon is not identified in the younger Tecovas and Cooper Canyon horizons. However, in India and Germany it occurs throughout the Carnian (Roy Chowdhury 1965).

\section{Node 2. Amniota: Therapsida}

Dicynodontia - The dicynodonts were dominant herbivores in Late Permian faunas, but had gradually dwindled in importance by the Late Triassic. Their herbivorous specializations include the absence of teeth, a pair of maxillary tusks, and propalinal motion of the jaw. Late Triassic dicynodonts were large browsers, about $3 \mathrm{~m}$ long. A new dicynodont taxon has been recognized recently in Texas on the basis of cranial and postcranial elements, but its affinity is not well resolved (Edler 1999). It occurs in the Cooper Canyon Formation, and may represent the last surviving lineage of dicynodonts. Late Triassic dicynodonts are rare, mainly represented by Ischigualastia, Dinodontosaurus, and Placerias. The former two genera are tuskless, but Placerias retained a small, almost hidden tusk. Forty individuals of Placerias were recovered from the aptly-named Placerias Quarry of Arizona (Camp and Welles 1956). Ischigualastia is known primarily from the Ischigualasto Formation of South America; however, Lucas and Hunt (1993b) described some fragmentary material including a scapula, radius and femur from the Santa Rosa Formation of New Mexico, and suggested that this taxon served as an index fossil for the 'Ischigualastian' biochron (Lucas 1998). We found a partial skull, mandible (figure 12A), and few postcranial elements of a new dicynodont in the Cooper Canyon Formation at the Neyland Quarry, thus extending the range of dicynodonts into the upper part of the Dockum Group (Norian). The new Texas dicynodont differs from all late Triassic genera with the development of a prominent tusk.

Cynodontia - The cynodonts include mammals and all other taxa that are closer to mammals than to dicynodonts. They appeared at the end of the Permian and radiated mainly in the Triassic. Three taxa of cynodonts are known on the basis of fragmentary remains from the Dockum, and all of these were very small animals, about the size of a rat. Pseudotriconodon is represented by several isolated teeth. Pachygenelus is known from a lower jaw and isolated teeth from the Cooper Canyon Formation of the Post Quarry (Chatterjee 1983). Adelobasileus, the earliest mammal, is known from a solitary braincase found in the Tecovas Formation (Lucas and Hunt 1990). The braincase is expanded and it is enclosed completely as in mammals. 


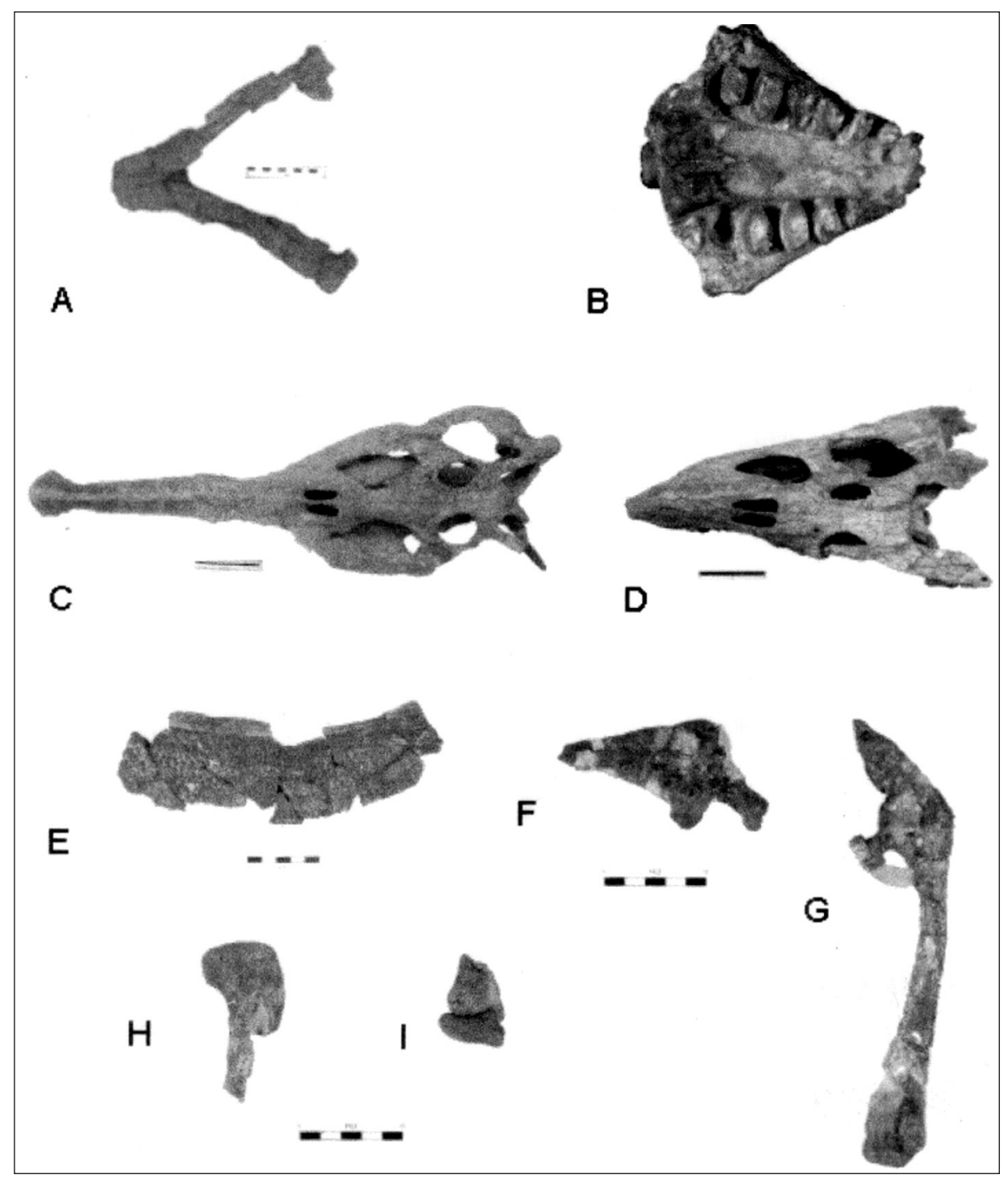

Figure 12. Some of the new Dockum tetrapods discussed in the text. (A) Mandible of a new dicynodont, occlusal view from Neyland Site, Cooper Canyon Formation (TTUP 9421); (B) skull of Libognathus, a procolophonid, left lateral view from Simpson Ranch, Cooper Canyon Formation (TTUP 10068); (C) skull of Paleorhinus, a primitive phytosaur, dorsal view, from the Neyland Site, Cooper Canyon Formation (TTUP 9423); (D) a partial skull of Redondasaurus, a derived phytosaur, doral view from the Macy Ranch, Cooper Canyon (TTU P9425); (E) right paramedian scute of a Typothorax from Patricia Site (TTUP 10070), Cooper Canyon Formation; F-I, postcranial elements of Coelophysis, a basal theropod dinosaur, from the Cooper Canyon Formation, Garza County; (F) right ilium, left lateral view, Post Quarry (TTUP 10071); (G) lateral view of a right pubis, Post Quarry (TTUP 10082); (H) proximal end of a left femur, caudal view (TTUP 10072), Lott Ranch; (I) conjoined distal end of tibia and astragalus, cranial view (TTUP 10072), Lott Ranch. Scale bar (A, C, D: $10 \mathrm{~cm} ; \mathrm{E}-\mathrm{I}: 5 \mathrm{~cm})$.

Node 3. Eureptilia: Anapsida: Procolophonidae

Procolophonids are first recognized in Late Permian faunas and became cosmopolitan during the Triassic. Small (1997) described a new procolophonid, Libognathus, from the Cooper Canyon Formation near the town of Post. It is based on a solitary left dentary with heterodont teeth. The rostral teeth are conical but the cheek teeth are transversely widened with a rostral transverse ridge forming a cusp labially and lingually.
Recently we have found a well preserved skull (figure 12B) and mandible of Libognathus, about $30 \mathrm{~mm}$ long, also from the Cooper Canyon Formation, which will provide important new anatomical information for this taxon.

\section{Node 4. Reptilia}

Reptiles are the dominant groups of tetrapods found in the Dockum Group. These include several clades, such as Diapsida, Archosauromorpha, 
Archosauriformes, Archosauria, Dinosauria, Theropoda, and Aves, in a phylogenetic hierarachy.

Node 5. Diapsida: Lepidosauria: Sphenodontia

Jaws with acrodont teeth resembling those of the modern Sphenodon are abundant, especially from the Tecovas Formation at the Kirkpatrick Quarry. They belong to the genus Clevosaurus where the upper and lower teeth are triangular and shear past each other. This taxon was widely distributed during Late Triassic and Early Jurassic time, and is known from North America, England, and China.

\section{Node 6. Archosauromorpha}

Three groups of archosauromorphs are known from the Dockum, trilophosaurids, rhynchosaurids, and prolacertiforms, all of which became extinct during Late Triassic time.

Archosauromorpha: Trilophosauridae - Gregory (1945) described excellent skeletons of Trilophosaurus from the Cooper Canyon Formation at the Otis Chalk locality in Howard County. The skull is heavily built where the lower temporal opening of the diapsid skull is secondarily closed off. The beak is edentulous but the cheek teeth are transversely expanded, tricuspid, and form sharp, shearing surfaces probably for processing tough plant food. Tooth implantation is ankylothecodont, and replacement is unique with wide anlage spacing. Isolated teeth of Trilophosaurus are common throughout the Tecovas and Cooper Canyon Formations. Recently, we have found a rich concentration of Trilophosaurus remains at the Neyland Quarry in Garza County. Trilophosaurus is so far known only from the southwestern United States.

Archosauromorpha: Rhynchosauridae - Rhynchosaurs were one of the most common groups of land vertebrates throughout the Triassic Period, being recorded from all continents except Australia and Antarctica. Late Triassic hyperodontine rhynchosaurs are known from Europe, India, Madagascar, South America, and North America. Rhynchosaur dentition is highly specialized. The premaxillae form an edentulous beak, like a pair of overhanging tusks. Each maxilla has a long, triangular tooth plate which is crowded with a number of longitudinal rows of small teeth, and is traversed by a longitudinal groove for the reception of the sharp, toothed surface of the dentary. The maxillary and dentary tooth plates are often found isolated and are the most diagnostic elements for identification of the group.

Hunt and Lucas (1991a) described a new rhynchosaur, Otischalkia, on the basis of fragmentary material including premaxillae, femora and humeri from the Cooper Canyon Formation at the Otis Chalk locality. However, Long and Murry (1995) concluded that some of the limb elements assigned to Otischalkia belong instead to a robust trilophosaurian. In fact, limb elements of basal archosauromorphs are so similar that the characters supporting Otischalkia are tenuous. Without a maxillary or a dentary tooth plate, the presence of rhynchosaurs in the Dockum is difficult to ascertain at present. If Otischalkia is confirmed on the basis of more diagnostic material from the Otis Chalk locality in the future, this would be the youngest occurrence of a rhynchosaur anywhere in the world. However, diagnostic rhynchosaur remains have been identified, but are yet to be described, from the Late Triassic Popo Agie Formation of Wyoming and the Wolfville Formation of Nova Scotia.

Archosauromorpha: Prolacertiformes - Prolacertiforms were very successful during Permo-Triassic time, and are recorded from all continents except South America. Chatterjee (1986b) described a new species of Malerisaurus from the Cooper Canyon Formation at the Otis Chalk locality. This species is a small, gracile, long-necked animal similar to bipedal lizards in size and proportion. The conspicuous elongated, amphicoelous vertebrae of Malerisaurus are common in both the Tecovas and Cooper Canyon formations. A large concentration of Malerisaurus bones has been found at the Neyland Quarry in Garza County. Malerisaurus is also known from the Maleri Formation of India.

\section{Node 7. Archosauriformes: Doswellia}

Weems (1980) described an enigmatic, densely armored archosauromorph from the Doswell Formation (Carnian) of the Newark Group in Virginia. In Doswellia, the skull is sculptured, the orbits are near the midline, the lower temporal opening is secondarily closed off, and the pterygoid is toothed. Long and Murry (1995) reported postcranial remains of Doswellia from the Otis Chalk localities. Lucas $(1990,1991)$ used Doswellia as one of the index taxa for the proposed 'Otischalkian' biochron. However, it remains occur throughout Carnian and Norian deposits (figure 13).

\section{Node 8. Archosauria}

Archosaurs were the dominant terrestrial vertebrates of the Mesozoic Era. Cladistic analysis (Sereno 1992) recognizes two distinct lineages of crown groups among archosaurs, one leading to crocodilians (Crurotarsi), and the other to birds (Ornithodira). The former is characterized by a rotary, crurotarsal ankle joint, the latter by a mesotarsal joint. In the Dockum Group, the Crurotarsi is represented by several clades including phytosaurids, stagonolepidids, and rauisuchids. 


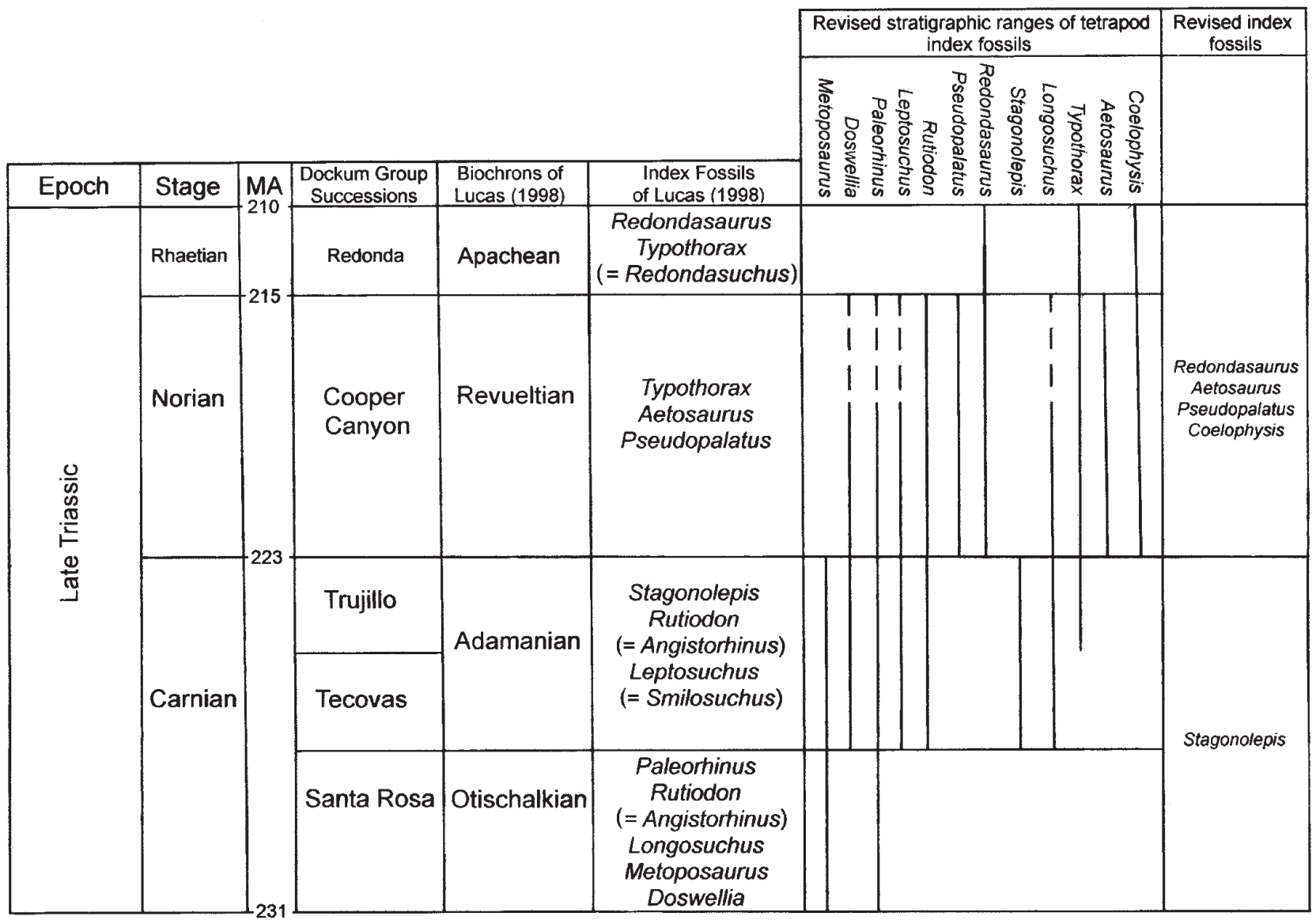

Figure 13. Biostratigraphic significance of Dockum tetrapods for subdivision of nonmarine Late Triassic strata. Lucas (1998) proposed four land-vertebrate faunachrons within the Dockum: Otischalkian, Adamanian, Revueltian and Apachean on the basis of supposed tetrapod index fossils. The temporal ranges of these index fossils, as shown on the right side of the chart, do not support four successive biochrons. Instead, Carnian and Norian stages can be demarcated on the basis of few index fossils, the Carnian stage by Stagonolepis, the Norian stage by Redondasaurus, Aetosaurus, Pseudopalatus, and Coelophysis.

Archosauria: Crurotarsi: Phytosauridae - Phytosaurs (or parasuchids) are long-snouted, carnivorous reptiles of Late Triassic age superficially resembling modern crocodiles (gharials) in size, proportions, and inferred activities. Their remains are among the most common and widespread vertebrate fossils, recorded from North America, Europe, India, Madagascar, North Africa, and Thailand. Currently the systematics of phytosaurs is in a state of flux. Five distinct taxa are recognized in the Dockum: Paleorhinus, Rutiodon (=Angistorhinus), Leptosuchus, Pseudopalatus, and Redondasaurus (Long and Murry 1995). Of these, Paleorhinus, Leptosuchus, and Rutiodon are generally considered to be primitive basal taxa, whereas Pseudopalatus and Redondasaurus are more derived.

Because of their widespread distribution and distinctive morphology, phytosaurs have been used as index fossils for subdivision of the Late Triassic (Gregory 1962; Chatterjee 1978; Hunt and Lucas 1991a; Lucas 1998). Recently, Hungerbühler and Sues (2001) concluded that Rutiodon and Angistorhinus are congeneric, the former is a senior synonym of the latter. They thus questioned the validity of the use of Rutiodon and Angistorhinus as index fossils for subdivision of the Carnian as proposed by Lucas (1998). Rutiodon remains have been recovered from both the Tecovas and Cooper Canyon. Hunt and Lucas (1991b) proposed that Paleorhinus characterized a limited stratigraphic interval restricted to the Early Carnian (pre-Tecovas) and erected the 'Otischalkian' biozone in part on this basis. However, we have recovered a skull and associated skeleton of Paleorhinus from the Cooper Canyon Formation at the Neyland Quarry (Simpson 1998) indicating that the 'Otischalkian' biozone cannot be substantiated on the basis of phytosaur occurrence (figure 12C). Hence, primitive phytosaur taxa such as Paleorhinus and Rutiodon appear to have longer stratigraphic ranges through the Dockum Group sequence than 
was formerly believed. Recognition of Leptosuchus from the Post Quarry (Norian) likewise invalidates its use in demarcating Carnian deposits. Similarly, Hunt and Lucas (1993a) named Redondasaurus from the Redonda Formation of New Mexico as the most derived phytosaur, where the upper temporal fenestrae are concealed in dorsal view. They claimed that Redondasaurus is restricted to the Rhaetic, and erected the 'Apachean' biozone in part on the basis of this taxon. However, we have collected a skull (figure 12D) and articulated skeleton of Redondasaurus from the lower part of the Cooper Canyon Formation. This occurrence extends the stratigraphic range of Redondasaurus downward (McQuilkin 1998); and so the 'Apachean' biochron cannot be defined on the basis of this taxon range zone. A large concentration of Pseudopalatus remains occurs at the Patricia Site in the upper part of the Cooper Canyon Formation. Pseudopalatus and Redondasaurus occur only in the Cooper Canyon Formation. Hence, these phytosaur genera may be useful as index fossils for demarcating the Carnian from Norian stages, but further subdivision within each stage does not appear to be possible.

Archosauria: Crurotarsi: Stagonolepididae Stagonolepidids (or aetosaurs) are massively built, armored, quadrupedal herbivores ranging from 1 to $6 \mathrm{~m}$ in body length. The skull is relatively small with an upturned, edentulous snout, and the cheek teeth are peg-like and constricted at their bases. Stagonolepidids are known from Upper Triassic deposits of North and South America, Europe, Greenland, Africa, and India. The morphology and ornamentation of their dermal armor have traditionally been used for classification of stagonolepidids. Currently, five valid genera are recognized in the Dockum: Stagonolepis, Typothorax, Desmatosuchus, Longosuchus, and Paratypothorax (Long and Murry 1995). Redondasuchus (Hunt and Lucas 1991a) from the Redonda Formation of New Mexico is considered a junior synonym of Typothorax (Long and Murry 1995). Similarly, Lucasuchus (Long and Murry 1995) is regarded as a junior synonym of Longosuchus (Heckert and Lucas 2000). Excellent skeletons of Desmatosuchus, Typothorax and Paratypothorax have been collected from the same stratigraphic level of the Cooper Canyon Formation at the Post Quarry and are well-represented in the collections of the Museum of Texas Tech University (Small 1989). Stagonolepis is restricted to the Tecovas Formation (Long and Murry 1995). Longosuchus is known from the Trujillo and Cooper Canyon, Desmatosuchus from Tecovas through Cooper Canyon, Typothorax from the Santa Rosa to Redonda Formation (figure 12E), and Paratypothorax from Tecovas through Cooper Canyon. Aetosaurus is also known from the Cooper Canyon and Redonda Formations. Various attempts have been made recently to subdivide continental Late Triassic deposits on the basis of stagonolepidids (Hunt and Lucas 1992; Lucas et al 1995; Heckert and Lucas 1998, 2000). However, from our analysis, it appears that most of the stagonolepidid taxa have long temporal ranges, extending from the Carnian through the Norian, and have little biostratigraphic utility. However, two taxa, Stagonolepis and Aetosaurus, also known from Europe, appear to have restricted ranges. Stagonolepis occurrences are restricted to Carnian deposits, whereas Aetosaurus distribution is confined to the Norian.

Crurotarsi: Rauisuchidae - Rauisuchids were top predators in Triassic ecosystems. They possessed a large and narrow skull, keyhole-shaped orbits, large, serrated teeth, and erect postures. Currently, four taxa are recognized in the Dockum on the basis of pelvic structure: Postosuchus, Lythrosuchus, Poposaurus, and Chatterjeea (Chatterjee 1985; Long and Murry 1995). Poposaurus and Lythrosuchus are known from fragmentary material, but Postosuchus and Chatterjeea are wellrepresented by several skeletons in the collection of the Museum of Texas Tech University. All four taxa are present from the Tecovas through the Cooper Canyon and have little biochronological utility for subdivision of the Dockum succession.

\section{Node 9. Dinosauria}

In contrast to non-dinosaurian archosaurs, dinosaur remains are sparse and fragmentary in the Dockum, but they may provide crucial insights into the Late Triassic radiation of several lineages, including the ornithischians, theropods, and early birds.

Dinosauria: Ornithischia - Ornithischian dinosaurs are rare components in Late Triassic tetrapod asemblages. Other than the poorly preserved Pisanosaurus from the Ischigualasto Formation of Argentina (Bonaparte 1976), Late Triassic ornithischians are virtually unknown except for isolated teeth. Chatterjee (1984) described a basal ornithischian, Technosaurus, on the basis of premaxilla and dentary bones with well-preserved teeth, a caudal part of the mandible, a dorsal vertebra and an astragalus. The tooth crowns are subtriangular, leaf-shaped, tricuspid, and separated from the roots by a constriction. These teeth are hallmarks of basal ornithischians such as fabroasaurids. The tooth crown is symmetrical in labio-lingual view, and bi-convex. Although Technosaurus remains are fragmentary, its ornithischian affinity has been accepted by later workers (Weishampel and Witmer 1990). However, Sereno (1991) claimed that the holotype of Technosaurus 
represents two taxa. He hypothesized that only the tooth-bearing dentary belongs to an ornithischian, while the premaxilla and the caudal part of the mandible may instead represent a prosauropod. However, the third tooth in the premaxilla is biconvex in labio-lingual cross-section, and tricuspid with a constricted neck, similar in morphology to the dentary teeth assigned to Technosaurus. In contrast, premaxillary teeth in prosauropods are spatulate, with numerous, obliquely angled marginal serrations. Moreover, interdental plates border the lingual surface of prosauropod teeth; these plates are absent in this premaxilla. Similarly, the caudal part of the mandible bears a small surangular foramen as seen in Lesothosaurus. This feature is absent in prosauropods. We could not find any size discrepancy between the dentary and the caudal part of the mandible. Thus, Sereno's reasonings for allocating the premaxilla and the caudal part of the mandible to a prosauropod are unfounded. They belong to Technosaurus.

Several isolated teeth have been attributed to basal ornithischians such as Revueltosarus from the Cooper Canyon of New Mexico (Hunt 1989) and Tecovasaurus from the Tecovas Formation of Texas (Hunt and Lucas 1994). We are not certain whether these isolated teeth can be confidently referred to Ornithischia. Later, Heckert and Lucas (1998) claimed that Technosaurus and Revueltosaurus are restricted to the Cooper Canyon, and Tecovasuchus to the Tecovas Formation. However, the sample size of basal ornithischians is so small and fragmentary that their biostratigraphic utility cannot be ascertained at present.

\section{Node 10. Theropoda}

Theropoda: Coelophysis - Although hundreds of articulated skeletons of Coelophysis have been recovered from the Upper Chinle Group of Ghost Ranch, New Mexico, no definite Coelophysis remains have been documented from the Dockum Group of Texas (Colbert 1989). Here we report two specimens of Coelophysis from Texas, both collected from the Cooper Canyon Formation in Garza County (figure 12F-12H). One specimen represents a string of vertebrae, the proximal end of a left femur, the distal end of a left tibia, and an associated astragalus, all from the Lott Ranch. The femur shows both the fourth trochanter and a lesser trochanter and the highly inturned head (figure $12 \mathrm{H}$ ). The tibia and astragalus are not fused but separate elements where the ascending process of the astragalus locks into a notch of the distal end of the tibia (figure 12I). The second specimen is a right ilium, somewhat smaller in size (figure 12F). It shows a perforated acetabulum and a distinctive brevis shelf. Both specimens resemble Coelophysis bauri. Ceolophysis appears to be restricted to the Norian and it may be useful as an index fossil.

Theropoda: Shuvosaurus - Chatterjee (1993) described the skull of an unusual theropod, Shuvosaurus, from the Cooper Canyon Formation of the Post Quarry. Shuvosaurus manifests a suite of characters currently known in ornithomimosaurs such as toothless jaws, enormous eye sockets, a reduced jugal, a slit-like lower temporal opening, and specialization in the otic capsule. However, Shuvosaurus lacks the expanded parasphenoid capsule and large endocranial cavity typical in ornithomimosaurs. Because of these contrasting characters, as well as a lack of postcranial material, the phylogenetic position of Shuvosaurus within theropods is problematic. Chatterjee (1993) offered two hypotheses: either Shuvosaurus is a basal theropod but shows a stunning convergence with ornithomimosaurs; or it is the oldest member of the ornithomimosaur lineage. Recent assessment of Shuvosaurus by Rauhut (1997) supports the former possibility. Additional cranial and postcranial material suggests that Shuvosaurus is more derived than ceratosaurs. Parrish and Carpenter (1986) described an edentulous premaxilla from the Cooper Canyon of New Mexico that may belong to Shuvosaurus.

\section{Node 11. Aves: Protoavis}

Chatterjee $(1991,1997,1999)$ described the earliest bird, Protoavis, from the Dockum Group. Protoavis appears to be more derived than the Jurassic bird, Archaeopteryx. Protoavis is a small, gracile bird, about the size of a pheasant with a long bony tail. It has a kinetic skull like modern birds and acquired powered flight. The remains of Protoavis have been found both in the Tecovas and Cooper Canyon Formations. The occurrence of Protoavis pushes the time of avian origins back to the Late Triassic.

\section{Late Triassic vertebrate biochronology}

The Late Triassic $(\sim 231-210 \mathrm{Ma})$ was an extraordinary time in tetrapod evolution. Several major tetrapod groups such as lissamphibians, squamates, crocodilians, dinosaurs, birds and mammals first appeared in the fossil record during this time. All continents remained united as Pangea, although rifting in the region including eastern North America, southern Europe, and North Africa during the Late Triassic marked the early phase in development of the North Atlantic Ocean. As Pangea began to break apart, regression of epeiric seas and widespread emergence of 
the continents resulted in deposition of nonmarine Triassic red beds in many areas around the globe (Chatterjee 1997). A more precise correlation of these nonmarine Triassic strata is an important step in understanding the history of physical and biological events on land during this critical time. Tetrapod fossils provide one of the principal tools for correlation of nonmarine Triassic strata across Pangea to the type sequence of the Triassic in Germany. The Pangean supercontinent was symmetrically disposed about the equator at that time, and climate was relatively uniform from the equator to high latitudes. Terrestrial tetrapods were able to migrate easily across the land surface, and therefore many species appear to have had a cosmopolitan distribution.

In Germany, the Triassic section is divisible into three sequential lithostratigraphic units: Buntsandstein (Lower Triassic), Muschelkalk (Middle Triassic), and Keuper (Upper Triassic). The Buntsandstein and Keuper are continental, whereas the intervening Muschelkalk is marine. The whole Triassic sequence in Germany represents a major transgressive/regressive cycle in which the continental red beds of the Buntsandstein pass gradually upwards into Muschelkalk carbonates and evaporites and back into continental Keuper red beds (Aigner and Bachman 1992). Peak transgression occurred during the Late Muschelkalk. The Late Triassic terrestrial sediments of Germany are geographically close to the equivalent marine rocks in the Alps, and attempts have been made to establish a detailed correlation between the two. The Keuper interval has been subdivided and correlated with three marine stages of the Alps: Carnian (231-223 Ma), Norian (223$215 \mathrm{Ma}$ ) and Rhaetian (215-210 Ma; Aigner and Bachmann 1992). However, the Rhaetian is of very limited duration, and its ammonoid fauna cannot be clearly distinguished from that of the underlying Norian Stage (Tozer 1984). Many stratigraphers advocate abandonment of the Rhaetian Stage altogether, and consider it to be part of the Norian. The Carnian-Norian boundary appears to lie between the Bunte Mergel and Stubensandstein in Germany.

In the Dockum Group, vertebrate fossils generally occur in pockets in the mudstones of the Tecovas and Cooper Canyon Formations; the intervening Trujillo Sandstone is poorly fossiliferous. Similarly, the Santa Rosa Sandstone has yielded few tetrapods except for metoposaurs and phytosaurs. The paucity of tetrapods in the Santa Rosa and Trujillo Sandstones makes precise biostratigraphic correlation difficult. The phytosaurs, metoposaurs, stagonolepidids, and rauisuchids in the Dockum Group show striking resemblances to those of Keuper beds of Germany, and this supports a Late Triassic age assignment. On the basis of tetrapod assemblages, Chatterjee (1986a) correlated the Tecovas and Trujillo with the Carnian Stage of Germany, and the overlying Cooper Canyon with the Norian Stage. The boundary between the Carnian and Norian appears to lie between the Trujillo Sandstone and the Cooper Canyon Formation (figure 2). Cornet (1993) studied the palynomorphs from the Tecovas and Trujillo Formations and inferred a Middle to Late Carnian age for them.

During the last ten years, S G Lucas and his associates have proposed a detailed vertebrate biostratigraphy for the Dockum Group of Texas and eastern New Mexico (Lucas 1990, 1991, 1993, 1997, 1998; Lucas and Hunt 1987, 1993a, 1993b; Lucas et al 1995; Heckert and Lucas 1996, 1998, 1999, 2000; Hunt 1993; Hunt and Lucas 1990, 1991a, 1991b, 1992, 1993a, 1993b, 1994, 1995, 1997). They recognize four global land-vertebrate 'faunachrons' using Dockum tetrapods as important index fossils. The 'faunachrons' were designated Otischalkian, Adamanian, Revueltian, and Apachean in ascending order. In their biochronology, the Otischalkian and Adamanian are subdivisions of the Carnian Stage, Revueltian is correlative with the Norian, and the Apachean with the Rhaetian stages of the marine Alpine section (figure 13). However, our studies have found that the stratigraphic ranges of many Dockum tetrapods actually overlap one another, and are not restricted in the manner supposed by Lucas and his associates. Unlike marine invertebrates, continental tetrapods appear to offer only coarse temporal resolution. The revised taxonomic status and stratigraphic ranges of the index taxa of Lucas and his associates, amplified by our collections, provides little support for the four successive biochrons of the Dockum Group that they have proposed. We have plotted the stratigraphic ranges of the important tetrapod taxa to test the validity of the proposed land vertebrate biochronology (figure 13).

The 'Otischalkian' is the oldest of the faunachrons in the biostratigraphy advocated by Lucas and associates. It was established largely on the basis of collections made from the classical sites near Otis Chalk. Because of the supposedly 'primitive' elements of the Otis Chalk fauna, they believed that the strata in this area were older than the Tecovas Formation, and have referred to these strata variously as the 'Iatan Member' or more recently as the 'Colorado City Member' of the Dockum. However, our mapping shows that these strata are actually within the upper part of the Cooper Canyon Formation (see discussion by Lehman 1994a, p. 49-51). Hence, in spite of the 'primitive' aspects of the Otis Chalk fauna, it actually occurs very high 
stratigraphically within the Dockum succession. Both the Otis Chalk sites and the Neyland Site, which is unquestionably within the Cooper Canyon Formation, have virtually identical faunal assemblages, including Paleorhinus, Buetternia, Malerisaurus, and Trilophosaurus, supporting a close lithostratigraphic and biostratigraphic correlation of these two sites. Other supposed Otischalkian index fossils such as Rutiodon, Longosuchus, and Doswellia have long ranges, extending from Carnian to Norian (figure 13; Long and Murry 1995; Hungerbühler and Sues 2001). Thus, the Otischalkian biochron cannot be supported on the basis of available tetrapod evidence. In reality, the Otischalkian and the Revueltian faunas are coeval on the basis of lithostratigraphic correlation. On the other hand, the Adamanian fauna appears to be roughly equivalent to those found in deposits correlated with the Carnian Stage in other parts of the world.

Similarly, Lucas and his associates proposed the 'Apachean' faunachron primarily on the basis of two index fossils, Redondasaurus and Typothorax (=Redondasuchus) found at sites in the Redonda Formation. However, we have collected the same two taxa from the Cooper Canyon Formation in Garza County (Small 1989; McQuilkin 1998). Here, the 'Apachean' fauna occurs in strata that also yield a supposed Revueltian fauna. This new evidence precludes the basis for erecting another biochron; the 'Apachean' cannot be supported. The Redonda and Cooper Canyon Formations appear to be in part laterally equivalent to one another. Long and Lehman (1994) dated detrital biotite samples (likely derived through reworking of ash) from the upper part of the Cooper Canyon Formation that yielded a $\mathrm{Rb} / \mathrm{Sr}$ isotopic age of approximately $210 \mathrm{Ma}$. Hence, it is possible that strata correlative with the Rhaetian Stage are indeed present in the Dockum Group. However, if the Norian-Rhaetian Stage boundary occurs within these strata, it is not associated with any distinctive faunal turnover. None of the typical Rhaetic fauna in Germany, such as haramiyids, tritylodontids, or plateosaurs have been found in the Redonda or Cooper Canyon Formations, indicating that direct biostratigraphic correlation between these strata and the Rhaetian Stage cannot be made.

The four land-vertebrate 'faunachrons' of Lucas and his associates do not meet the requirements for useful biostratigraphic (or chronostratigraphic) units. It appears that only strata correlative with the Carnian and Norian Stages can be demarcated and correlated with those of Germany, on the basis of a few tetrapod index taxa. Further biostratigraphic subdivision of each stage is not currently possible on the basis of nonmarine tetrapods.
Deposits correlative with the Carnian Stage can be recognized by the presence of the stagnolepidid Stagnolepis. Deposits correlative with the Norian Stage have two distinct phytosaurs, Redondasaurus and Pseudopalatus, the stagnolepidid Aetosaurus, and possibly the basal theropod Coelophysis. We have found little biostratigraphic evidence for major generic level evolutionary change within the Dockum succession. Out of thirty-two genera of tetrapods, only one taxon is restricted to Carnian strata and four to Norian strata; the majority of taxa occur throughout the entire range of fossilbearing sediments in the Dockum Group (figures 4, 13). Our data do not support the Carnian-Norian tetrapod extinction event advocated by Benton (1986, 1991). The pattern of distribution among genera of large tetrapods represents, in our opinion, ecological factors, not a pattern of rapid evolution or extinction at the generic level.

\section{Conclusions}

Triassic strata of the Dockum Group in west Texas are comprised largely of two typical alluvial facies associations; stream channel facies, and overbank flood-plain facies, similar to those described in nearly all fluvial deposits. In addition, the Dockum Group contains a unique lacustrine facies, that accumulated in local flood-plain depressions. These depressions probably resulted from subsidence over areas of subsurface salt dissolution. The lacustrine deposits exhibit penecontemporaneous deformation, and evidence for multiple episodes of subsidence, erosion, and sedimentation. This unique lacustrine facies association differs from those described in most other fluvial successions, but strikingly resembles Tertiary and Quaternary lacustrine 'playa' deposits found in the High Plains region of Texas, which likely also resulted from dissolution-induced subsidence. Vertebrate fossil accumulations occur in all three facies associations and each provides a varied sample of aquatic, semi-aquatic, or terrestrial elements of the Triassic ecosystem.

A review of the Dockum tetrapods is presented to discuss the current taxonomic status of various genera, their relationships, and stratigraphic ranges. Tetrapod fossils appear to be of only limited utility for biochronology of Late Triassic nonmarine strata. The four purported biochrons (Otischalkian, Adamanian, Revueltian, and Apachean) recognized within the Dockum Group by S Lucas and his associates are not supported by biostratigraphic evidence. Detailed sampling of Dockum tetrapod remains from multiple localities indicates that the stratigraphic ranges for most supposed tetrapod index fossils actually 
overlap one another. The absence or presence of a given tetrapod at any particular locality likely reflects ecological factors rather than extinction or origination events. At present, the stratigraphic distribution of Dockum tetrapods supports only correlation with strata equivalent to the Carnian and Norian Stages of Germany. The boundary between the Trujillo and the Cooper Canyon Formations approximates the stage boundary. Further biostratigraphic subdivision of the Dockum Group does not appear to be possible at present.

\section{Acknowledgements}

We thank Asru Chaudhuri for inviting us to contribute this paper for the memorial volume of Professor S K Chanda, a pioneer sedimentologist in India. We thank the many land owners in west Texas who have given us permission to conduct a research on their properties over the years, among them Riley Miller, Bob Macy, Jack and Zoe Kirkpatrick, Patricia Kirkpatrick, Giles McCrary, Jim Boren, Jack Lott, and Fred Humble. We also thank the many volunteers, and undergraduate and graduate students, who have assisted with our research on the Dockum Group, among them Father Malcolm Neyland, Doug Cunningham, Andrew Frelier, Brent May, Teresa Fritz, John Schnable, Cam Kanhalangsy, Eric Simpson, Kyle McQuilkin, Amy Edler, Bill Mueller, Jeff Martz, Momchil Atanassov, and Jonathan Weinbaum. We thank Axel Hungerbuehler, Kyle McQuilkin, Bill Mueller, Martin Gibling, and Bruce Rubidge for helpful discussions and constructive suggestions. The National Geographic Society and Texas Tech University have supported our research on the Dockum Group for many years. We thank Patricia Kirkpatrick and John Lott for their generous financial support and encouragement for the project. The illustrations in this report are the work of Tom Lehman and Kyle McQuilkin, and photographs are by Bill Mueller.

\section{References}

Aigner T and Bachmann G H 1992 Sequence-stratigraphic framework of the German Triassic; Sediment. Geol. 80 $115-135$.

Allen J R L 1965 Fining-upwards cycles in alluvial successions; Geol. J. 4 229-246.

Allen J R L 1984 Sedimentary structures, their character and physical basis; Developments in Sedimentology 30 1-663 (Elsevier: Amsterdam).

Allen P A 1981 Devonian lake margin environments and processes, southeast Shetland, Scotland; J. Geol. Soc. London 138 1-14.

Benton M J 1986 The Late Triassic tetrapod extinction events; In: The beginning of the age of dinosaurs (ed.)
K Padian, (Cambridge: Cambridge University Press) Pp. 303-320.

Benton M J 1991 What really happened in the late Triassic? Hist. Biol. 5 263-278.

Benton M J 1997 Vertebrate paleontology (London: Chapman and Hall).

Bolt J R and Chatterjee S 2000 A new temnospondyl amphibian from the Late Triassic of Texas; J. Paleont. 74 670-683.

Bonaparte J F 1976 Pisanosausus mertii casamiquela and the origin of Ornithischia J. Paleont. 50 808-820.

Bonython C W and Mason B 1953 The filling and drying of Lake Eyre; Geog. J. 199 321-330.

Boone J L 1979 Lake margin depositional systems of the Dockum Group (Upper Triassic) in Tule Canyon, Texas Panhandle; M.A. thesis, University of Texas, Austin.

Camp C L and Welles S P 1956 Triassic dicynodont reptiles: Part 1. The North American genus Placerias; Mem. Univ. California 13 255-304.

Cant D J and Walker R G 1978 Fluvial processes and facies sequences in the sandy braided South Saskatchewan River; Sedimentol. 25 625-648.

Caran S C and Baumgardner R W Jr 1986 Measured section, Smith Farm, Quitaque, Texas, In: Geomorphology and Quaternary stratigraphy of the Rolling Plains, Texas Panhandle (ed.) Gustavson T C, University of Texas at Austin, Bureau of Economic Geology, Guidebook 22 63-66.

Case E C 1928 Indications of a cotylosaur and of a new form of fish from the Triassic beds of Texas, with remarks on the Shinarump Conglomerate. Univ. Michigan Contr. Mus. Paleont. 3(1) 1-14.

Case E C 1932 A collection of stegocephalians from Scurry County, Texas; Univ. Michigan Contr. Mus. Paleont. 4(1) $1-56$.

Chatterjee S 1978 A primitive parasuchid (phytosaur) reptile from the Upper Triassic Maleri Formation of India. Palaeont. 21(1) 83-127.

Chatterjee S 1983 An ictodosaur fossil from North America Science 220 1151-1153.

Chatterjee S 1984 A new ornithischian dinosaur from the Triassic of North America Naturwissenschaften 71 630-631.

Chatterjee S 1985 Postosuchus, a new thecodontian reptile from the Triassic of Texas and the origin of tyrannosaurs. Phil. Trans. R. Soc. London B309 395-460.

Chatterjee S 1986a The Late Triassic Dockum vertebrates: their stratigraphic and paleobiogeographic significance; In: The beginning of the age of dinosaurs (ed.) K Padian (Cambridge: Cambridge University Press), Pp. 139-150.

Chatterjee S 1986b Malerisaurus langstoni, a new diapsid reptile from the Triassic of Texas; J. Vert. Paleont. 6 $297-312$

Chatterjee S 1991 Cranial anatomy and relationships of a new Triassic bird from Texas; Phil. Trans. R. Soc. London B352 277-342.

Chatterjee S 1993 Shuvosaurus, a new theropod; Nat. Geog. Res. Expl. 9 274-285.

Chatterjee S 1997 The rise of birds (Baltimore: Johns Hopkins University Press).

Chatterjee S 1999 Protoavis and the early evolution of birds; Palaeontograph. A254 1-100.

Colbert E H 1989 The Triassic dinosaur Coelophysis; Mus. North Arizona Bull. 57 1-160.

Cornet B 1993 Applications and limitations of palynology in age, climate, and paleoenvironmental analysis of Triassic sequences in North America; New Mexico Mus. Nat. Hist. Bull 3 75-93. 
Dane C H and Bachman G O 1965 Geologic map of New Mexico: U.S. Geol. Surv. New Mexico Bur. Mines Min. Res., scale 1:500,000.

Davidow-Henry B 1993 Small metoposaurid amphibians from the Triassic of western North America and their significance; In: Dawn of the age of dinosaurs; (eds.) S G Lucas and A P Hunt (Albuquerque: New Mexico Museum of Natural History), Pp. 278-292.

Dubiel R 1987 Sedimentology of the Upper Triassic Chinle Formation, southeastern Utah: paleoclimatic implications; J. Arizona-Nevada Acad. Sci. 22 35-45.

Edler A 1999 Late Triassic dicynodonts: their anatomy, relationships, and paleobiogeography; MA thesis, Texas Tech University, Lubbock.

Elder R L 1978 Paleontology and paleoecology of the Dockum Group, Upper Triassic, Howard County, Texas; M.A. thesis, University of Texas, Austin.

Frelier A P 1987 Sedimentology, paleohydrology, and paleogeomorphology of the Dockum Formation (Triassic), West Texas; M.S. thesis, Texas Tech University, Lubbock.

Fritz T 1991 Depositional History of the Mid-Late Triassic Santa Rosa Formation, Eastern New Mexico; M.S. thesis, Texas Tech University, Lubbock.

Galloway W E 1989 Genetic stratigraphic sequences II: application to northwest Gulf of Mexico Cenozoic basin; Am. Assoc. Petrol. Geol. Bull. 73 143-154.

Gould C N 1907 The geology and water resources of the western portion of the Panhandle of Texas; U.S. Geol. Surv. Water Supply Paper 191 1-70.

Gregory J T 1945 Osteology and relationships of Trilophosaurus; Univ. Texas Publ. 4401 273-359.

Gregory J T 1962 The genera of phytosaurs; Am. J. Sci. $260652-690$.

Heckert A B, Hunt A P and Lucas S G 1996 Redescription of Redondasaurus reseri, a late Triassic aetosaur (Reptilia: Archosauria) from New Mexico (U.S.A.), and the biochronology and phylogeny of aetosaurs; Geobios 29 619-632.

Heckert A B and Lucas S G 1996 First occurrence of Aetosaurus (Reptilia: Archosauria) in the Upper Triassic Chinle Group (U.S.A.) and its biochronologic significance; N. Jb. Geol. Paläont. Mem. 10 604-612.

Heckert A B and Lucas S G 1998 First use of ornithischian dinosaur for biostratigraphic zonation of the Upper Triassic; Albertina 58-63.

Heckert A B and Lucas S G 1999 A new aetosaur from the upper Triassic of Texas and the phylogeny of aetosaurs; J. Vert. Paleont. 19 50-68.

Heckert A B and Lucas S G 2000 Taxonomy, phylogeny, biostratigraphy, biochronology, paloebiogeography, and evolution of the Late Triassic Aetosaurua (Archosauria; Crurotarsi); Z. Geol. Paläont. 11-12 1539-1587.

High L R and Picard M D 1965 Sedimentary petrology and origin of analcime-rich Popo Agie Member, Chugwater (Triassic) Formation, West-central Wyoming; J. Sediment. Petrol. 35 49-70.

Hungerbuhler A and Sues H D 2001 Status and phylogenetic relationships of the Late Triassic Rutiodon caroliensis J. Vert. Paleont. 21(3) 64A.

Hunt A P 1989 A new ornithischian dinosaur from the Bull Canyon Formation (Upper Triassic) of east-central New Mexico; In: Dawn of the age of dinosaurs (eds) S G Lucas and A P Hunt (Albuquerque: New Mexico Museum of Natural History), Pp. 355-358.

Hunt A P 1993 Revision of the Metoposauridae (Amphibia: Temnospondyli) and description of a new genus from western North America; Mus. North Arizona Bull. 59 $67-97$.
Hunt A P and Lucas S G 1990 Re-evaluation of 'Typothorax' meadei, a Late Triassic aetosaur from the United States; Paläont. Z. 64 317-328.

Hunt A P and Lucas S G 1991a A rhynchosaur from West Texas (USA) and the biochronology of Late Triassic rhynchosaurs; Palaeont. 34 191-198.

Hunt A P and Lucas S G 1991b The Paleorhinus biochron and the correlation of the non-marine Upper Triassic of Pangea; Palaeont. 34 487-501.

Hunt A P and Lucas S G 1992 The first occurrence of the Paratypothorax andressi (Reptilia, Aetosauria) in the western United States and its biochronological significance; Paläont Z. 66 147-157.

Hunt A P and Lucas S G 1993a Triassic vertebrate paleontology and biochronology of New Mexico; New Mexico Mus. Nat. Hist. Sci. Bull. 2 49-62.

Hunt A P and Lucas S G 1993b A new phytosaur (Reptilia: Archosauria) genus from the uppermost Triassic of western United States and its biochronologic significance; New Mexico Mus. Nat. Hist. Sci. Bull. 3 193-196.

Hunt A P and Lucas S G 1994 Ornithischian dinosaurs from the Upper Triassic of the United States; In: In the shadow of the dinosaurs: early Mesozoic tetrapods (eds) N C Fraser and H D Sues (Cambridge: Cambridge University Press), Pp. 225-241.

Hunt A P and Lucas S G 1995 Vertebrate paleontology and biochronology of the lower Chinle Group (Upper Triassic) Santa Fe County, north-central New Mexico; New Mexico Geol. Soc. Guide Book 46 243-246.

Hunt A P and Lucas S G 1997 Stratigraphy, paleontology and biochronology of the Upper Triassic Chinle Group in east-central New Mexico; In: Southwest Paleontological Symposium Proceedings (eds) B Anderson, D Boaz and R D McCord (Mesa: Mesa Southwest Museum), 1 25-40.

Johns D A and Granata G E 1987 Regional tectonic setting and depositional trends of the Dockum Group, West Texas and Eastern New Mexico; Arizona-Nevada Acad. Sci. J. 22 53-72.

Kanhalangsy K 1997 Petrography, geochemistry, and clay mineralogy of a paleosol in the Dockum Group (Triassic), Texas Panhandle; M.S. thesis, Texas Tech University, Lubbock.

Kietzke K and Lucas S G 1991 Ostracoda from the Upper Triassic (Carnian) Tecovas Formation near Kalgary, Crosby County, Texas; Texas J. Sci. 43 191-197.

Kraus M J and Bown T M 1986 Paleosols and time resolution in alluvial stratigraphy, In: Paleosols, their recognition and interpretation (ed) V P Wright (New Jersey: Princeton University Press), Pp. 180-207.

Lehman T M 1992 Stratigraphic nomenclature of the Triassic Dockum Group in West Texas and eastern New Mexico; New Mexico Geol. 1476.

Lehman T M 1994a The saga of the Dockum Group and the case of the Texas/New Mexico boundary fault; New Mexico Bureau Mines Min. Res. Bull. 150 37-51.

Lehman T M 1994b Save the Dockum Group; West Texas Geol. Soc. Bull. 34 5-10.

Lehman T M, Chatterjee S and Schnable J 1992 The Cooper Canyon Formation (Late Triassic) of western Texas; Texas J. Sci. 44 349-355.

Lehman T M and Schnable J P 1992 Triassic sedimentation in West Texas and eastern New Mexico; Soc. Econ. Paleont. Min. 1992 Theme Meeting, Mesozoic of the Western Interior, Abstracts 39.

Lehman T M, Frelier A, May B, Fritz T and Schnable J (in preparation) Sedimentation and tectonism in the Triassic Dockum Basin, southern High Plains of Texas and New Mexico. 
Long L E and Lehman T M 1993 Rb-Sr ages of detrital mica in sandstones of the Triassic Dockum Group, Texas Panhandle; Geol. Soc. Am. Abs. Prog. 25 A66.

Long L E and Lehman T M 1994 Mid-Paleozoic age of provenance of Triassic (Dockum Group) sandstone, Texas Panhandle, U.S.A; U.S. Geol. Surv. Cir. 1107197.

Long R A and Murry P A 1995 Late Triassic (CarnianNorian) tetrapods from the Southwestern United States; New Mexico Mus. Nat. Hist. Bull. 4 1-254.

Lucas S G 1990 Toward a vertebrate biochronology of the Triassic; Albertina 8 36-41.

Lucas S G 1991 Sequence stratigraphic correlation of nonmarine and marine Late Triassic biochronologies, western United States; Albertina 9 11-18.

Lucas S G 1993 The Chinle Group: revised stratigraphy and chronology of the Upper Triassic nonmarine strata in the western United States; Mus. North. Arizona Bull. 59 $27-50$.

Lucas S G 1997 Upper Triassic Chinle Group, western United States: a nonmarine standard for Late Triassic time; In: Late Palaeozoic and early Mesozoic Circum Pacific events and their global correlation (eds) J M Dickins, H Yin, S G Lucas and S K Acaharyya (Cambridge: Cambridge University Press), Pp. 209-228.

Lucas S G 1998 Global Triassic tetrapod biostratigraphy and biochronology; Palaeogeog. Palaeoclimatol. Palaeoecol. 143 347-384.

Lucas S G and Anderson O J 1992 Triassic stratigraphy and correlation, west Texas and eastern New Mexico; Trans. Southwest Sec., Amer. Assoc. Petrol. Geol. West Texas Geol. Soc. Publ. SWS 92-90 201-207.

Lucas S G and Anderson O J 1993 Lithostratigraphy, sedimentation, and sequence stratigraphy of Upper Triassic Dockum Formation, West Texas; Trans. Southwest Sec., Am. Ass. Petrol. Geol., Fort Worth Geol. Soc. 55-65.

Lucas S G, Heckert A B and Hunt A P 1995 Unusual archosaurs (Archosaurua: Aetosauria) from the American Southwest; Paläont. Z. 69 467-473.

Lucas S G and Hunt A P 1987 Stratigraphy of the Anton Chico and Santa Rosa Formations, Triassic of Eastcentral New Mexico; Arizona-Nevada Acad. Sci. J. 22 21-33.

Lucas S G and Hunt A P 1989 Revised Triassic stratigraphy in the Tucumcari Basin, east-central New Mexico; In: Dawn of the Age of Dinosaurs in the American Southwest (eds) S G Lucas and A P Hunt (Albuquerque: New Mexico Museum of Natural History), Pp. 150-170.

Lucas S G and Hunt A P 1990 The oldest mammal; New Mexico J. Sci. 30 41-49.

Lucas S G and Hunt A P 1993a Tetrapod biochronology of the Chinle Group (Upper Triassic), western United States; New Mexico Mus. Nat. Hist. Sci. Bull. $\mathbf{3}$ 327-329.

Lucas S G and Hunt A P 1993b A dicynodont from the Upper Triassic of New Mexico and its biochronological significance; New Mexico Mus. Nat. Hist. Sci. Bull. 3 321-325.

Lucas S G, Hunt A P and Morales M 1985 Stratigraphic nomenclature and correlation of Triassic rocks of eastcentral New Mexico: a preliminary report; New Mexico Geol. Soc., 36th Field Conf. Guidebook 171-184.

May B A 1988 Depositional environments, sedimentology, and stratigraphy of the Dockum Group (Triassic) in the Texas Panhandle; M.S. thesis, Texas Tech University, Lubbock.

May B A and Lehman T M 1989 Sedimentology of the Dockum Group (Triassic) in the Texas Panhandle; San Angelo Geol. Soc., Trans. Southwest Sec. Meeting, Am. Assoc. Petrol. Geol. 49-53.
McGowen J H, Granata G E and Seni S J 1979 Depositional framework of the lower Dockum Group (Triassic), Texas Panhandle; Univ. Texas Bur. Econ. Geol. Rep. Invest. 97 $1-60$.

McGowen J H, Granata, G E and Seni S J 1983 Depositional setting of the Triassic Dockum Group, Texas Panhandle and Eastern New Mexico; Rocky Mountain Sec., Soc. Econ. Paleont. Min., Rocky Mountain Paleogeog. Symp. 2 13-38.

McKee E D, Crosby E J and Berryhill H L Jr. 1967 Flood deposits, Bijou Creek, Colorado, June 1965; J. Sediment. Petrol. 37 829-851.

McQuilkin K 1998 An articulated phytosaur skeleton: preparation techniques from field to exhibit; MA thesis, Texas Tech University, Lubbock.

Murry P A 1989 Geology and paleontology of the Dockum Formation (Upper Triassic), West Texas and eastern New Mexico, In: Dawn of the Age of Dinosaurs in the American Southwest (eds) S G Lucas and A P Hunt (Albuquerque: New Mexico Museum of Natural History), Pp. 102-144.

Olsen P E 1990 Tectonic, climatic, and biotic modulation of lacustrine ecosystems examples from Newark Supergroup of eastern North America, In: Lacustrine basin exploration (ed.) B J Katz; Am. Assoc. Petrol. Geol. Mem. 50 209-224.

Parrish J M and Carpenter K 1986 A new vertebrate fauna from the Dockum Formation (Late Triassic) of eastern New Mexico; In: The beginning of the age of dinosaurs (ed.) K Padian (Cambridge: Cambridge University Press), Pp. 151-160.

Pipringos G N and O'Sullivan R B 1978 Principal unconformities in Triassic and Jurassic rocks, Western Interior United States - a preliminary survey; U.S. Geol. Surv. Prof. Pap. 1035A 1-29.

Rauhut O W M 1997 On the cranial anatomy of Shuvosaurus inexpectatus (Dinosauria; Theropoda); Terra Nostra 7 $1-4$.

Reeves C C Jr 1990 A proposed sequential development of lake basins, Southern High Plains, Texas and New Mexico; In: Geologic framework and regional hydrology: Upper Cenozoic Blackwater Draw and Ogallala formations, Great Plains (ed.) T C Gustavson Univ. Texas Austin, Bur. Econ. Geol., Guidebook 24 209-232.

Riggs N R, Lehman T M, Gehrels G E and Dickinson W R 1996 Detrital zircon link between headwaters and terminus of the Upper Triassic Chinle-Dockum paleoriver system; Science $\mathbf{2 7 3}$ 97-100.

Roth R 1955 Paleogeology of Panhandle of Texas; Bull. Am. Petrol. Geol. 39 422-443.

Roy Chowdhury T 1965 A new metoposaurid amphibian from the Upper Triassic Maleri Formation of Central India; Phil. Trans. R. Soc. London B250 1-52.

Sawin H J 1947 The pseudosuchian reptile Typothorax meadei; J. Paleont. 21 201-238.

Schnable J P 1994 Sedimentology of the Upper Triassic Dockum Group in the Canadian River Valley of Texas and New Mexico; M.S. thesis, Texas Tech University, Lubbock.

Sereno P C 1991 Lesothosaurus, 'fabrosaurids', and the early evolution of Ornithischia; J. Vert. Paleont. 11 168-197.

Sereno P C 1992 Basal archosaurs: phylogenetic relationships and functional implications; J. Vert. Paleont. 11(4) $1-53$.

Simpson E O 1998 The phylogeny and biostratographic utility of parasuchids from the Dockum Group of West Texas; M.S. thesis, Texas Tech University, Lubbock.

Small B J 1989 Aetosaurs from the Upper Triassic Dockum Formation, Post quarry, West Texas; In: Dawn of the age 
of dinosaurs in the American Southwest (eds) S G Lucas and A P Hunt (Albuquerque: New Mexico Museum of Natural History), Pp. 301-308.

Small B J 1997 A new procolophonid from the Upper Triassic of Texas, with a description of tooth replacement and implantation; J. Vert. Paleont. 17 674-678.

Smith N D 1970 The braided stream depositional environment: comparison of the Platte River with some Silurian clastic rocks, north-central Appalachians; Geol. Soc. Am. Bull. 81 2993-3014.

Sneh A 1983 Desert stream sequences in the Sinai Peninsula. J. Sediment. Petrol. 53 1271-1279.

Stear W M 1983 Morphological characteristics of ephemeral stream channel and overbank splay sandstone bodies in the Permian Beaufort Group, Karoo Basin, South Africa; In: Modern and Ancient Fluvial Systems (eds) J D Collinson and J Lewin, Int. Assoc. Sediment. Spec. Publ. 6 405-420.

Suchecki R K, Hubert J F and Birney de Wet C C 1988 Isotopic imprint of climate and hydrogeochemistry on terrestrial strata of the Triassic-Jurassic Hartford and Fundy rift basins; J. Sediment. Petrol. 58 801-811.

Tozer E T 1984 The Triassic and its ammonoids: the evolution of a time scale; Geol. Surv. Canada Misc. Rep. 35 $1-171$.
Tunbridge I P 1984 Facies model for a sandy ephemeral stream and clay playa complex: the Middle Devonian Trentishoe Formation of North Devon, U.K.; Sediment. 31 697-715.

Turner C E and Fishman N S 1991 Jurassic Lake T'oo'dichi': a large saline lake, Morrison Formation, Colorado Plateau; Geol. Soc. Amer. Bull. 103 538-558.

Weems R E 1980 An unusual newly discovered archosaur from the Upper Triassic of Virginia, U.S.A.; Am. Phil. Soc. Trans. 70(7) 1-53.

Weishampel D B and Witmer L M 1990 Lesothosaurus, Pisanosaurus, and Technosaurus; In: Dinosauria (eds) D B Weishampel, P Dodson and H Osmolska (Berkeley: University of California Press), Pp. 416-425.

Wells N A 1983 Transient streams in sand-poor redbeds: Early-Middle Eocene Kuldana Formation of northern Pakistan; In: Modern and Ancient Fluvial Systems (eds) J D Collinson and J Lewin, Int. Assoc. Sediment. Spec. Publ. 6 393-403.

Wilson G A 1988 The effects of subsurface dissolution of Permian salt on the deposition, stratigraphy, and structure of the Ogallala Formation (Late Miocene) northeast Potter County, Texas; M.S. thesis, West Texas State University, Canyon.

Wilson J A 1948 A small amphibian from the Triassic Howard County, Texas; J. Paleont. 22 359-361. 